\title{
Pemikiran KH. Abdurrahman Wahid Tentang Sistem Pendidikan Pesantren
}

\author{
Samsul Bahri \\ Fakultas Tarbiyah dan Ilmu Keguruan \\ IAIN Kendari \\ Kendari, Indonesia \\ smsulbahri1@gmail.com
}

\begin{abstract}
This dissertation is based on the demand of changes towards boarding school institution, which becomes academic debates about tradition and modernization of boarding school education system by Islamic scholars and thus becomes challenges for boarding schools. This research discussed boarding school education system based on the point of view of KH. Abdurrahman Wahid. This research design by using library research as the instrument with a descriptive analysis of historical approach and pedagogical comparative. The primary source of the data is the work by KH. Abdurrahman Wahid, such as Menggerakkan Tradisi; Esai-Esai Pesantren, BungaRampai Pesantren: Kumpulan KaryaTulis Abdurrahman Wahid, "Pesantren as a subkultur, in M. Dawam Rahardjo (ed), Pesantren dan perubahan, Islam kosmopolitan, Islamku Islam Anda Islam Kita, as primary sources.

This paper concludes that the thinking of KH. Abdurrahman Wahid about boarding school education system is essential in responding to the changes by keep referring to the boarding schools subcultures. It can be seen from some of KH Abdurrahman Wahid's thoughts, such as, first, the aim of boarding school education is dynamic does not only mean to tafaqqu fi al-din, but also to gain knowledge on religious sciences and others. So that students have extensive knowledge, religious knowledge, and general knowledge and skills. Second, the educational program of boarding school education is adaptively by maintaining integrated the curriculum of Islamic sciences and others by simplifying the boarding school curriculum and adjusting it into the development of sciences and technology. Third, the process of boarding school education is innovative by maintaining learning methods sorogan and wetonanthe main characters of boarding school education; however, efforts to the perfect educational system at boarding school must be continually made, especially those related to methods of teaching and implementation of materials in the boarding school.

Besides promoting the important findings above, this dissertation recommends to manager and development of boarding school education system to be more competitive, relevant to the needs of society, and able to answer the demands of the times in accordance with the potential and distinctiveness Islamic boarding schools.
\end{abstract}

Keyword: changing demands, pesantren education system, Gus Dur thinking

Abstrak

Disertasi ini dilatarbalakangi pada terjadinya tuntutan perubahan terhadap institusi pendidikan pesantren yang menjadi debat akademik tentang tradisi dan modernisasi sistem pendidikan pesantren yang dikemukakan para tokoh-tokoh pendi dikan Islam yang banyak memunculkan tantangan bagi pesantren. Karena itu, penelitian ini dirumuskan untuk mendeskripsikan sistem pendidikan pesantren berdasarkan pemikiran KH. Abdurrahman Wahid. Kajian ini, menggunakan instrumen penelitian kepustakaan (library research), berdasarkan metode deskriptisanalitis dengan pendekatan historis, paedagogik serta komparatif. Sumber utama Menggerakkan 
Tradisi; Esai-Esai Pesantren. Bunga Rampai Pesantren; Kumpulan Karya Tulis Abdurrahman Wahid, sebagai sumber primer melalui metode dokumentasi.

Disertasi ini berhasil menyimpulkan bahwa pemikiran KH. Abdurrahman Wahid tentang sistem pendidikan pesantren adalah bersifat integral dalam merespon perubahan dengan tetap merujuk pada subkultur pesantren. Kebenaran kesimpulan ini didasarkan pada beberapa aspek yaitu: Pertama, aspek tujuan pendidikan pesantren bersifat dinamis tidak hanya pada upaya tafaqquh fi al-din, tetapi juga diperluas dengan penguasaan ilmu pengetahuan dan teknologi, sehingga santri memiliki wawasan yang luas, menguasai ilmu agama dan ilmu pengetahuan umum serta keterampilan. Dengan demikian, tujuan bergerak ke arah integrasi tujuan yaitu keseimbangan antara keimanan, ketaqwaan (Imtaq) dan penguasaan ilmu pengetahuan (Iptek). Tujuan ini harus dirumuskan secara tertulis. Kedua, aspek program pendidikan bersifat adaptif dengan tetap mempertahankan kitab-kitab klasik untuk mempertahankan reproduksi ulama, dan menggunakan integrasi kurikulum antara ilmu-ilmu agama dan umum, dengan menyederhanakan kurikulum pesantren, yang disesuaikan dengan perkembangan pengetahuan dan teknologi. Ketiga, aspek proses pendidikan pesantren, bersifat inovatif dengan tetap menerapkan metode pembelajaran sorogan dan wetonan yang menjadi ciri khas pendidikan pesantren, namun sebaiknya ada usaha-usaha untuk menyempurnakan sistem pengajaran yang ada di pesantren harus diteruskan, dan mengenai materi pelajaran sepanjang menyangkut tata nilai dan pandangan hidup yang ditimbulkannya di pesantren, harus tetap dikembangkan karena memiliki cukup banyak kelebihan.

Selain mempromosikan temuan penting di atas, disertasi ini merekomendasikan kepada pengelolah dan pengembangan sistem pendidikan pesantren untuk lebih kompetitif, relevan dengan kebutuhan masyarakat dan mampu menjawab tuntutan zaman, sesuai dengan potensi dan kekhasan pendidikan pesantren itu sendiri, dengan tetap mempertahankan budaya pesantren.

Kata Kunci: sistem pendidikan pesantren karakter bangsa

\section{A. Pendahuluan}

Pesantren menurut Martin van Bruinessen adalah sistem pendidikan Islam di Indonesia yang memiliki tradisi agung (great tradition), yang pengajaran agama Islam mempunyai keunggulan, baik dalam tradisi keilmuannya maupun pada sisi transmisi dan internalisasi moral. Di sisi lain, pesantren juga merupakan pendidikan yang dapat memainkan peran pemberdayaan masyarakat (empowerment) dan transformasi sosial secara efektif. Peran inilah yang membuat sistem pendidikan pesantren sebagai lembaga pendidikan tradisional mampu bertahan (survive) sampai sekarang. Disertasi ini memusatkan pada sistem pendidikan pesantren, dengan mengambil kajian pemikiran tokoh yang lahir dari dunia pesantren yang dikenal sebagai seorang pemikir yang mempunyai gagasan pluralisme, multikultularisme, dan pribumisasi, serta dikenal seorang politisi yang tidak bisa dipisahkan dari sejarah kontroversi di negeri ini yaitu KH. Abdurrahman Wahid.

Masalah tersebut penting untuk dikaji, mengingat pesantren merupakan institusi pendidikan yang melembaga dalam subkultur masyarakat Indonesia. Pesantren tidak hanya mengandung unsur keaslian (indigenous) Indonesia, tetapi juga identik dengan makna keislaman, sebab lembaga serupa juga ada pada masa kekuasaan Hindu-Budha, sedangkan Islam meneruskan dan mengislamkannya. ${ }^{1}$ Pada mulanya, identitas pesantren hanya sebagai lembaga pendidikan, penyiaran agama Islam, reproduksi ulama, pemeliharaan Islam

${ }^{1}$ Nurcholish Madjid, Bilik-Bilik Pesantren: Sebuah Potret Perjalanan, (Jakarta: Paramadina, 1997, cet ke- I), hlm. 3. 
tradisional. ${ }^{2}$ Dewasa ini telah terjadi banyak perubahan yang menimbulkan pengaruh terhadap institusi pesantren, namun demikian, pesantren tetap pada fungsi aslinya yang selalu dipelihara di tengah-tengah arus perubahan, ${ }^{3}$ dan mampu eksis dalam era globalisasi ini, ${ }^{4}$ serta berfungsi sebagai elemen determinan dalam struktur piramida sosial masyarakat Indonesia. Bahkan menjadi cerminan perpaduan antara pesantren dan lingkungan sosial, ${ }^{5}$ yang memiliki konstribusi signifikan sebagai agen perubahan sosial di negeri ini. ${ }^{6}$

Dilihat dari konteks perkembangan dunia yang semakin berkembang, maka fungsi pokok pendidikan pesantren yang disebutkan tadi, justru semakin relevan di tengah arus globalisasi yang menurut Adian Husaini adalah bagian dari imprealisme budaya (cultural imperialism) Barat terhadap budaya-budaya lain, yang melanggar nilai-nilai moral agama. ${ }^{7}$ Maka pendidikan pesantren, harus memainkan peran pesantren sebagai "cultural broker" (pialang budaya) dan kemampuan pesantren dalam mengontrol perubahan nilai. ${ }^{8}$ Berangkat dari permasalahan perubahan pendidikan pesantren di atas, maka kajian tentang sistem pendidikan pesantren dalam pemikiran KH. Abdurrahman Wahid menjadi kajian yang menarik untuk diteliti. Hal ini disebabkan karena KH. Abdurrahman Wahid tokoh yang dikenal mempunyai gagasan-gagasan mengenai kenegaraan, kebudayaan, dan demokrasi. Bahkan beliau dikenal tokoh agama, pemimpin ormas, intelektual, maupun politisi yang kontroversi. Ternyata memiliki gagasan tentang sistem pendidikan pesantren dalam menghadapi modernisasi. Karena itu, studi ini berupaya mengkaji dan membahas sistem pendidikan pesantren dalam menghadapi tantangan modernisasi menurut pemikiran $\mathrm{KH}$. Abdurrahman Wahid.

1. Bagaimana sistem pendidikan pesantren menurut pemikiran KH. Abdurrahman Wahid?

2. Bagaimana konsep pendidikan pesantren KH. Abdurrahman Wahid dalam menghadapi tantangan modernisasi?

\section{B. Teori Tentang Pesantren}

Pesantren menurut Kamus Besar Bahasa Indonesia berarti asrama tempat santri atau murid-murid belajar mengaji. ${ }^{9}$ Akar kata pesantren berasal dari kata santri yaitu istilah yang pada awalnya digunakan bagi orang-orang yang menuntut ilmu agama di lembaga pendidikan tradisional Islam Jawa dan Madura. ${ }^{10}$ Dalam pengertian yang sempit santri seorang yang belajar agama. Sedangkan pengertian yang umum, santri mengacu pada seorang anggota bagian penduduk Jawa yang menganut Islam dengan sungguh-sungguh,

2Dawan Rahardjo, Pergulatan Dunia Pesantren; Membangun Dari Bawah, (Jakarta: LP3ES, 1985), hlm.vii. Lihat juga Husni Rahim, Arah Baru Pendidikan Islam di Indonesia, (Jakarta: Logos, 2007), hlm. 147.

${ }^{3}$ Mundzier Suparta, Perubahan Orientasi Pondok Pesantren Salafiyah, Terhadap Prilaku Keagamaan Masyarakat, (Jakarta: Asta Buana Sejahtera, 2009), hlm. 2.

4Zaenal Khafidin,"Model Pendidikan Pesantren Madrasah," dalam Jurnal Penelitian, (STAIN Kudus, Vol. 2, No. 1, 2008), hlm. 249.

${ }^{5}$ Sahal Mahfudh, Nuansa Fiqih Sosial, (Yogjakarta: LKiS, 1994), hlm. 342. 1984), hlm. 9.

${ }^{6}$ KH. Abdurrahman Wahid, Bunga Rampai Pesantren; Kumpulan Karya Tulis, (Jakarta: Dharma Bhakti,

${ }^{7}$ Adian Husain, Wajah Peradaban Barat; Dari Hegemoni Kristen ke Dominasi Sekular-Liberal, (Jakarta: Gema Insani, 2005), hlm. 20-27.

${ }^{8}$ Ahmad Tafsir, Ilmu Pendidikan Islam, hlm. 296 hlm. 878 .

${ }^{9}$ Tim Penyusun Kamus Pusat Pembinaan dan Pengembangan Bahasa, kamus Besar Bahasa Indonesia,

${ }^{10}$ Ali Anwar, Pembaharuan Pendidikan di Pesantren Lirboyo Kediri, hlm. 21. 
rajin shalat, pergi ke mesjid pada hari Jumat. ${ }^{11}$ Pesantren menurut Mastuhu suatu lembaga pendidikan tradisional Islam untuk mempelajari, memahami, mendalami, menghayati dan mengamalkan ajaran Islam dengan menekankan pentingnya moral keagamaan sebagai pedoman prilaku sehari-hari. ${ }^{12}$ Pesantren sendiri menurut pengertian dasarnya adalah tempat belajar para santri. Sedangkan pondok berarti rumah atau tempat tinggal sederhana yang terbuat dari bambu. Kata pondok berasal dari bahasa Arab "Funduq" yang berarti "Hotel atau asrama". ${ }^{13}$ Namun demikian, jika membicarakan mengenai pesantren berarti praktis mempunyai; pondok, mesjid, santri, kiai, serta kitab-kitab Islam klasik. ${ }^{14}$ Setidaknya ditemukan empat teori tentang asal kata santri, yaitu adaptasi dari bahasa Sansekerta, Jawa, Tamil dan India. Abu Hamid menganggap bahwa perkataan pesantren berasal dari bahasa Sanskerta yang memperoleh wujud dan pengertian tersendiri dalam bahasa Indonesia. Ia berasal dari kata sant yang berarti orang baik dan disambung dengan kata tra yang berarti menolong. Jadi santra berarti tempat orang baik yang suka menolong. Sedangkan pesantren berarti tempat untuk membina manusia menjadi orang baik. ${ }^{15}$ Nurcholish Madjid mengajukan pendapat bahwa asal usul perkataan santri itu berasal dari kata Sansekerta yang artinya melek huruf dan juga berasal dari bahasa Jawa cantrik artinya seorang yang mengabdi kepada seorang guru. ${ }^{16}$

Asumsi di atas tidak sepenuhnya benar, hal ini jika ditelusuri melalui komparasi kedua sistem (sistem pendidikan Islam dan sistem pendidikan pra Islam) dimana materi pengajaran dalam cantrik lebih mengedepankan pada pelatihan pisik yang dalam istilah disebut ilmu kanuragan. Adapun materi yang diajarkan dalam pesantren pada umumnya lebih bersifat ilmu pengetahuan keagamaan. Kenyataan tersebut, memberi gambaran yang jelas bahwa titik perbedaan antara pola pendidikan cantrik dengan pola pendidikan pesantren. Bukti lain, bahwa dalam dunia Islam sendiri terdapat sistem pendidikan pesantren di Indonesia, ini telihat dari banyaknya instansi-instansi keagamaan di negara-negara Islam yang sistem pendidikannya sama seperti pesantren di Indonesia. Seperti yang terdapat di Yaman dengan Darul Mustofa-nya atau di Saudi Arabia dengan Rubat-nya. ${ }^{17}$

Pendapat di atas, memupuskan asumsi bahwa pesantren adalah budaya tradisional Indonesia yang mengalami Islamisasi, dan dari sisi lain bisa simpulkan bahwa pesantren merupakan bagian dari budaya Islam yang telah mengalami pribumisasi ketika masuk keindonesia. Pesantren menurut Abdurrahman Wahid suatu tempat yang dihuni oleh para

${ }^{11}$ Clifford Geertz, Abangan, Santri, dan Priyayi Dalam Masyakat Jawa, terjemahan Aswab Mahasin, (Jakarta: Pustaka Jaya, 1983), hlm. 268. Lihat juga Ali Anwar, Pembaharuan Pendidikan di Pesantren Lirboyo Kediri, hlm. 23.

${ }^{12}$ Lihat Mastuhu, Dinamika Pendidikan Pesantren, h. 55. Bandingkan dengan Zamakhsyari Dhofier, Tradisi Pesantren, (Jakarta, LP3ES, 2011), hlm. 18.

${ }^{13}$ Kelangsungan hidup suatu pesantren amat tergantung kepada daya tarik tokoh sentral (kiyai) yang memimpin, meneruskan atau mewarisinya. Hasbullah, Sejarah Pendidikan Islam di Indonesia, (Jakarta: Raja Grafindo Persada, 1999), hlm.138

${ }^{14}$ Lihat Andi M. Ramli, Gambaran Singkat tentang Pendidikan di Pesantren, dalam Buletin Bina Pesantren, (Jakarta: Depag RI, Juli 1999), hlm. 6.

${ }^{15}$ Abu Hamid,"Sistem Pendidikan Madrasah dan Pesantren di Sulawesi Selatan", dalam Taufik Abdullah (Ed), Agama dan Perubahan Sosial, (Jakarta: Rajawali Press, 1983), hlm. 328

${ }^{16}$ Nurcholish Madjid, Bilik-Bilik Pesantren;hlm. 19-20.

${ }^{17}$ Samsul Nizar et. al, Sejarah Sosial dan Dinamika Intelektual Pendidikan Islam di Nusantara, (Jakarta: Kecana, 2013), hlm. 139 
santri, dan mempunyai ciri-ciri pondok sebagai lingkungan pendidikan yang integral. ${ }^{18}$ Pernyataan ini menunjukkan makna keterkaitan pesantren dengan santri yang tidak bisa pisahkan, sehingga Dhofier mengsinyalir pesantren berasal dari kata santri di tamba awalan pe dan akhiran an berarti tempat tinggal para santri. ${ }^{19}$ Bahkan Dhofier merangkum pendapat Johns bahwa istilah santri berasal dari bahasa Tamil yang berarti guru mengaji, sedang C.C. Breg berpendapat bahwa istilah shastri yang dalam bahasa India berasal dari kata shastra yang berarti buku suci, buku agama dan buku tentang ilmu pengetahuan. ${ }^{20}$ Namun demikian, pondok menjadi unsur penting dalam institusi pesantren. ${ }^{21}$ Secara terminologis pesantren adalah lembaga pendidikan tradisional untuk mempelajari, memahami, menghayati, dan mengamalkan ajaran Islam dengan menekankan pentingnya moral keagamaan sebagai pedoman prilaku sehari-hari. ${ }^{22}$ Pendapat ini juga dikemukakan Mahmud Yunus bahwa pesantren adalah tempat santri-santri atau murid yang belajar ilmu Agama Islam, sehingga menjadi guru agama dan muballigh-muballigh Islam yang menyiarkan agama Islam ke seluruh pulau Jawa. ${ }^{23}$

Pendapat para ahli di atas, memberikan konsep pemahaman bahwa pesantren adalah lembaga yang memiliki keunikan dan berbeda dengan lembaga pendidikan lainnya dalam menyelenggarakan sistem pendidikan dan pengajaran agama, hal inilah yang melatarbelakangi perbedaan pandangan tentang teori mengenai asal usul pesantren bahkan sampai kepada tipologi pesantren. Distingsi tersebut, menyebabkan pesantren mempunyai tiga istilah yang disandangnya yaitu: Pertama, pesantren sebagai lembaga pendidikan Islam indigenous yang memiliki makna keislaman, juga mengadung makna keaslian Indonesia ${ }^{24}$ yang muncul dan berkembang dari pengalaman sosiologis religius masyarakat lingkungannya, dimana pesantren mempunyai kaitan erat dengan kemunitas lingkungannya. ${ }^{25}$ Tegasnya pesantren telah mengambil peran penting dalam proses Islamisasi masyarakat nusantara dan telah diakui keberadaanya sebagai agent of culture yang mampu untuk mempertasikan pesan-pesan ajaran agama dan menerapkan secara fungsional dalam kehidupan sehari-hari. Hal tersebut diakui Abdurrahman Wahid bahwa pesantren satu-satunya lembaga pendidikan yang menampung semua lapisan masyarakat untuk mendapatkan pendidikan dan memiliki dara biru kebangsawaan karena hubungan dengan lembaga pendidikan kekeratonan. ${ }^{26}$ Bahkan kemampuan pesantren sebagai swadaya masyarakat yang murni tidak bergantung kepada ketentuan-ketentuan asing, dengan mengembangkan kreativitas budaya lokal dan dinamika sosial lingkungannya berdasarkan nilai-nilai kepesantrenan yang diyakini dan dihayati secara mandiri. ${ }^{27}$

\footnotetext{
${ }^{18}$ Abdurrahman Wahid, "Pondok Pesantren Masa Depan” dalam buku Marzuki Wahid dkk, (penyunting), Pesantren Masa Depan Wacana Pemberdayaan dan Transformasi Pesantren, (Bandung: Pustaka Hidayah, 1999), hlm. 13

${ }^{19}$ Zamakhasyari Dhofier, Tradisi Pesantren; Studi Pandangan Hidup Kiai, hlm. 41

${ }^{20}$ Zamakhasyari Dhofier, Tradisi Pesantren; Studi Pandangan Hidup Kiai, hlm. 41

${ }^{21}$ M. Ali Sibram Malisi, Pembaharuan Pendidikan Pesantren, (Tangerang Selatan: YPM, 2013), hlm. 35.

${ }^{22}$ Mastuhu, Dinamika Sistem Pendidikan Pesantren, hlm. 55.

${ }^{23}$ Mahmud Yunus, Sejarah Pendidikan Islam di Indonesia, (Jakarta: Hidakarya, 1996), hlm. 231

${ }^{24}$ Nurcholish Madjid, Bilik-Bilik Pesantren Sebuah Potret Perjalanan, hlm. 3.

${ }^{25}$ Azyumardi Azra, Pendidikan Islam Tradisi dan Modernisasi, hlm. 108.

${ }^{26}$ KH. Abdurrahman Wahid, Prisma, (Yogyakarta: LKiS, 1999), hlm. 112.

${ }^{27}$ M. Habib Chirizin,'Pengejawatahan Nilai Pesantren secara Berperan Serta", dalam Pesantren No. 2, 1985, hlm. 29.
} 
Kedua, pesantren sebagai lembaga subkultur adalah tradisi yang hanya tumbuh dan berkembang di masyarakat pesantren. Walaupun istilah ini belum mendapatkan kesepakatan yang merata, namun penggunaan istilah ini kiranya lebih sebagai usaha pengenalan identitas kultural yang dilakukan oleh pihak luar terhadap dunia pesantren, yang memberi kesan isolasionis-eksklusif. ${ }^{28}$ Pesantren sebagai subkultur berkiprah di tengah-tengan masyarakat berdasarkan pada kultur yang bersifat keagamaan. Kultur tersebut mengatur prilaku seseorang dalam hubungannya antara warga masyarakat dengan masyarakat lain. ${ }^{29}$ Pesantren merupakan suatu komunitas tersendiri, dimana kiai, ustadz, santri dan pengurus santri hidup bersama dalam satu kampus berdasarkan nilai-nilai agama Islam, lengkap dengan norma-norma dan kebiasaan sendiri, yang secara eksklusif berbeda dengan masyarakat umum ia merupakan suatu keluarga besar di bawah pimpinan kiai atau ulama dengan dibantu ustadz. ${ }^{30}$ Dengan demikian, pesantren sebagai subkultur berada dalam tiga ciri utama yaitu: (1). Sistem nilai pesantren memiliki keunikan sendiri terpisah dari sistem nilai yang dianut masyarakat luar pesantren. (2). Pola kepemimpinan yang berdiri sendiri yang berbedah dengan kempemimpinan yang dianut masyarakat luar pesantren. (3). Gugusan penularan ilmu pengetahuan didasarkan pada literatur universal yang telah dipelihara sejak berabad-abad.

Ketiga, pesantren sebagai lembaga tradisional karena lembaga pendidikan ini lebih berorientasi kepada pengajaran dan penyebarluasan ilmu-ilmu keislaman tradisional seperti tauhid, tafsir, hadis, fiqih, tasawuf, akhlak dan sebagainya. ${ }^{31}$ Pesantren mempunyai peran tradisionalnya yang melekat pada dirinya yakni: (1) sebagai pusat berlangsungnya transmisi ilmu Islam tradisional, (2) sebagai pengjaga dan berlangsungnya Islam tradisional, dan (3) sebagai pusat reproduksi ulama. ${ }^{32}$

Tradisionalisme dalam definisi di atas, bukan berarti kolot dan ketinggalan zaman, tetapi merujuk kepada pengertian bahwa lembaga ini dari aspek historis yang ada sejak ratusan tahun (300-400 tahun) dan telah menjadi bagian yang tak terpisahkan dari sistem kehidupan umat Islam di Indonesia. Bahkan, telah mengalami perubahan dari waktu ke waktu sesuai dengan perjalanan hidup umat Islam. Jadi istilah tradisional di sini bukan dalam arti konsevatif dan ortodoks yang telah banyak mengalami sekularisasi. Tetapi tradisionalisme dalam pendidikan pesantren adalah istilah yang dipakai untuk menjelaskan Sunni Islam sepanjang sejarah Islam dan sangat berbeda dengan konsep konservatisme dan ortodoks dalam budaya Barat, karena itu, tradisionalisme pesantren adalah ketekunan dan kesabaran mencari ilmu, dinamisasi intelektual yang tetap menjaga nilai-nilai tradisi. ${ }^{33}$

Jika dianalisis pendapat di atas, maka ada dua teori utama dalam perdebatan tentang asal usul pesantren di Indonesia. Maka Zamaksyaris Dhofier menyebut bahwa pesantren berasal dari tradisi pesantren Timur tengah, bukan asli dari Indonesia. Menurut Dhofier, model pesantren yang ada di Jawa sekarang merupakan model gabungan antara madrasah dengan pusat tarekat yang ada di Timur Tengah. Demikian juga dengan Martin van Bruinessen dalam buku yang berjudul Kitab Kuning: Pesantren dan Tarekat, yang tidak

\footnotetext{
${ }^{28}$ KH. Abdurrahman Wahid, Bunga Rampai Pesantren, hlm. 9.

${ }^{29}$ Khaerul Wahidin, Pembaharuan Pondok Pesantren Masa Orde Baru, Disertasi (UIN Syarif Hidayatullah Jakarta, tidak diterbitkan, 2000), hlm. 32.

${ }^{30}$ Mastuhu, Dinamika Sistem Pendidikan Pesantren, hlm. 5.

${ }^{31}$ Suwito, Muhbib, Jaringan Intelektual Kyai Pesantren di Jawa-Madura Abad XX, dalam Laporan Hasil Penelitian Kompetitif, (Jakarta: Depertemen Agama RI, 2000), hlm. 1.

${ }^{32}$ Tim Peneliti, Peran Pesantren Dalam Penyelenggaraan Program Wajib Belajar 9 Tahun, (Jakarta: BalitBang Kemenag RI, Pusat UIN Jakarta, 1999), hlm. 4.

${ }^{33}$ Abdurrahman Mas'ud, Dari Haramain ke Nusantara; Jejak Intelektual Arsitek Pesantren, hlm. 276.
} 
sepakat dengan argumen bahwa pesantren merupakan kelanjutan dari sistem pendidikan Hindu-Budha sebelum datangnya Islam ke Indonesia. Menurut Martin, Al-Azhar merupakan tipologi awal dari model pesantren yang ada di Indonesia.Teori kedua menyatakan bahwa pesantren berasal dari tradisi pendidikan pra Islam atau pendidikan dalam tradisi Hindu Budha. Pendapat ini dikemukakan Manfried Zambek dalam buku Pesantren dan Perubahan Sosial. Menurutnya pola kelembagaan pesantren sekarang ini secara paralel merupakan kelanjutan dari lembaga pendidikan pra Islam yang sudah melembaga sebelumnya. Pendapat yang sama dikemukakan Nurcholish Madjid dalam buku Bilik-Bilik Pesantren: Sebuah Potret Perjalanan: mengakui bahwa pesantren yang ada sekarang ini merupakan kelanjutan dari pesantren era Hindu-Budha. Ketika Islam datang, tinggal memberi warna Islam pada lembaga pendidikan yang sudah ada.

Kedua teori di atas, memunculkan teori konvergensi menjadi acuan dalam melihat pesantren. Secara kelembagaan merupakan asimilasi dari model pendidikan luar baik pendidikan Islam di Timur Tengah maupun pendidikan Hindu-Budha yang masuk ke Indonesia. ${ }^{34}$ Hanun Asrohah dalam penelitiannya yang berjudul Pelembagaan Pesantren: Asal Usul Dan Perkembangan Pesantren di Jawa, menyimpulkan bahwa ciri pesantren ada pada pendidikan Hindu-Budha dengan tradisi asrama dan mandala, sedangkan model pendidikan kitab kuning mengacu pada pendidikan Timur Tengah. ${ }^{35}$ Karena itu, teori tersebut saling melengkapi antara satu dengan yang lain.

\section{Sketsa Biografi KH. Abdurrahman Wahid}

Nama sebenarnya adalah Abdurrahman ad-Dakhil dalam bahasa Indonesia berarti hamba Allah (Penyayang) Sang Penakluk. Penamaan Abdurahman ad-Dakhil oleh orang tuanya nampaknya taffa'ulan dengan Abdurrahman ad-Dakhil yang pernah memegang kekuasaan selama 32 tahun 756-788 M di Spanyol. Abdurrahman ad-Dakhil dalam sejarah Spanyol seorang pelarian yang menyeberangi daratan-daratan tandus dan bukit-bukit batu memasuki negeri sebagai orang asing yang tersisih. Tetapi, ia kemudian berhasil membangun kekuasaan, kemakmuran negeri, menyusun tentara dan mengatur pemerintahan. ${ }^{36}$ Belakangan kata addakhil tidak cukup dikenal dan diganti Wahid dan kemudian lebih dikenal dengan panggilan Gusdur.

${ }^{34}$ Wakhid Khozin, Pendidikan Kewargaan Pada Komunitas Pesantren, (Jakarta: Prasasti, 2007), hlm. 5.

${ }^{35}$ Hanun Asrohah, Pelembagaan Pesantren: Asal Usul dan Perkembangan Pesantren di Jawa, (Jakarta: Bagian Proyek Peningkatan Informasi Penelitian dan Diklat Keagamaan Departemen Agama RI. 2004), hlm. 5 .

${ }^{36}$ Tim INCReS, Beyond the Symbols; Jejak Antropologis Pemikiran dan Gerakan Gus Dur, (Bandung: Remaja Rosdakarya, 2000), hlm. 26. 
K.H. Abdurrahman Wahid adalah putra pertama dari enam bersaudara, ${ }^{37}$ yang panggilan populer Gus Dur ${ }^{38}$ lahir pada tanggal 4 Agustus $1940^{39}$ di Denannyar, dekat kota Jombang Jawa Timur dan meninggal 30 Desember 2009. Ayahnya bernama, K.H. Abdul Wahid Hasyim, adalah putra K.H. Hasyim Asy'ari, pendiri pondok pesantren Tebuireng dan pendiri Jam 'iyah Nahdatul Ulama (NU), organisasi Islam terbesar di Indonesia. Ibunya Hj Solehah, juga putri tokoh besar NU, KH. Bisri Syamsuri, pendiri pondok pesantren Denanyar Jombang dan Rois'Aam Syuriah PBNU setelah K.H. Abdul Wahab. ${ }^{40}$ Secara genetik Abdurrahman Wahid memiliki keturunan darah biru ${ }^{41}$ dan menurut Clifford Geertz, ia termasuk golongan santri dan priyayi sekaligus. ${ }^{42}$ Baik dari garis keturunan ayah maupun ibunya, ia adalah sosok yang menempati strata sosial tinggi dalam masyarakat Indonesia. Ia adalah cucu dari dua ulama terkemuka NU dan tokoh besar bangsa Indonesia. Kakeknya, Kiai Bisri Syamsuri dan kiai Hasyim Asy'ari, ${ }^{43}$ sangat dihormati di kalangan NU, baik karena peran mereka mendirikan NU maupun pengaruh mereka sebagai ulama. Dengan demikian, dapat dipahami bahwa beliau lahir dan dibesarkan dalam dunia pendidikan pesantren. Meskipun demikian, sejarah kehidupannya tidak mencerminkan seorang ningrat. Ia berproses dan hidup sebagaimana layaknya masyarakat pada umumnya.

Masa kecil KH. Abdurrahman Wahid tidak seperti kebanyakan anak-anak seusianya, yang tidak memilih tinggal bersama ayahnya, tetapi ikut bersama kakeknya. Ia diajari membaca al-Qur'an oleh kakeknya sendiri di pondok pesantren Tebuireng Jombang. Saat ia tinggal bersama kakeknya itulah, ia mulai mengenal politik dari orang-orang yang tiap hari hilir mudik di rumah kakeknya. Ayahnya KH. Wahid Hasyim adalah Menteri

37 Lima saudara Gus Dur secara berurutan adalah'Aisyah (Hj. 'Aisyah Hamid Baidlawi), Ir. H. Sholahuddin Wahid, dr. H. Umar Wahid, Khodijah dan Mohammad Hasyim.

${ }^{38}$ Gus adalah sebutan bagi seorang anak kiai, di Jawa Timur dan Jawa tengah "Gus" itu sebetulnya kependekan dari ucapan "Bagus", sebuah harapan seorang ayah kepada anaknya agar menjadi bagus. Panggilan ini umumnya ditujukan sebelum si anak menjadi kiai. Tetapi, dalam kenyataannya tidak sedikit orang yang sudah layak disebut kiai atau memang sudah menjadi kiai, masih dipanggil "Gus", K.H. Abdurahman Wahid adalah salah satu contoh yang paling populer. Panggilan "Gus" juga biasanya tetap dilekatkan bagi mereka yang anak kiai yang nyeleneh dan nakal, seperti Gus Miek, Gus Mus, Gus Ma'shum dan sebagainya. Panggilan Gus Dur memang terasa lebih dominan dan lebih menyatu ketimbang sebutan Kiai Haji Abdurrahman Wahid atau Kiai Abdurrahman. Karena itu, tanpa pretensi apapun kecuali alasan keumuman dan merasa lebih familiar. Selain itu sebutan Gus Dur agaknya telah menjadi sebuah fenomena tersendiri di Indonesia dan di dunia Intenasional, terutama karena perjuangannya yang gigih dan konsisten dalam menegakkan demokrasi, toleransi umat beragama dan penghargaan terhadap pluralisme di negara Pancasila ini. Perjuangan ini dilakukan baik saat berada di luar maupun di dalam pemerintahan Gus Dur seorang menjadi simbol bagi semua itu.

${ }^{39}$ Ahmad Bahar, Biografi Kiai Politik Abdurrahman Wahid; Gagasan dan Pemikiran, (Jakarta: Bina Utama, 1999), hlm. 2.

${ }^{40}$ Forum No. 1 tahun VI 21 April 1997, Gusdur, Diantara Keberhasilan dan Kenestapaan, h. 63.

${ }^{41}$ Ali Masykur Musa, Pemikiran dan Sikap Politik Gusdur, hlm. 4.

${ }^{42}$ Greetz, antropologi Amerika yang sangat terkenal, menemukan tiga varian Islam di Jawa khususnya dan di Indonesia pada umumnya, yakni priyayi, santri dan abangan. Untuk lebih jelasnya baca, Clifford Geertz, The Religion of Java, Glencoe, III Free Press, 1960.

${ }^{43}$ Kakek Abdurrahman Wahid dari pihak ibunya tidak setenar K.H. Hasyim Asy'ari dalam masyarakat kota yang sekuler. Namun ia pun bergerak aktif dalam pergerakan nasional. Beliau dilahirkan pada bulan September 1886 di daerah pesisir sebelah utara Jawa Tengah, sebuah daerah yang mempunyai banyak pesantren. Kakeknya dari pihak ayah K.H. Hasyim Asy'ari, dilahirkan di Jombang pada bulan Juli 1947, ia adalah salah seorang pendiri NU dan sangat dihormati sebagai seorang pemimpin Islam dalam masyarakat pedesaan yang tradisional. Ia juga dikenal sebagai seorang guru yang banyak memberi inspirasi serta seorang terpelajar. Namun ia juga seorang nasionalis yang teguh pendirian. Greg Barton, Biografi Abdurrahman Wahid, hlm. 26-29. 
Agama dan salah seorang dalam panitian sembilan yang merumuskan Piagam Jakarta, ${ }^{44}$ mungkin inilah awal KH. Abdurrahman Wahid harus bersntuhan dengan dunia luar pesantren. Semenjak ia berumur 4 tahun (1944) rela meninggalkan dunia pesantren dan ikut ke Jakarta bersama ayahnya. KH. Wahid Hasyim yang mempunyai rasa cinta terhadap masyarakatnya, sehingga ketika jabatan menteri Agama ada dipundaknya, beliau merasa terikat sehingga pergaulan dengan masyarakat kurang, akhirnya KH. Wahid Hasyim melepaskan jabatannya sebagai Menteri Agama.

Namun demikian, suatu kejadian pada hari sabtu 18 April 1953, KH. Abdurrahman Wahid berpergian menemani ayahnya untuk suatu pertemuan NU di Sumedang, yang dapat ditempuh dengan mobil dalam waktu beberapa jam saja dan terletak di sebelah tenggara Jakarta. Dijalan menuju kota Bandung yang berliku-liku dan ketika dalam perjalanan antara Cimahi dan Bandung, KH. Wahid Hasyim dan Abdurrahman Wahid bersama dengan Argo Sutjipto, seorang penerbit yang merupakan sahabatnya, mengalami kecelakaan, yang terjadi sekitar pukul 01.00 siang tetapi mobil ambulan dari Bandung baru tiba ditempat kejadian sekitar pukul 04.00 sore. Pada pukul 10.30 pagi kesokan harinya, KH. Hasyim Wahid tak lagi dapat bertahan dan meninggal dunia. Beberapa jam kemudian Argo juga meninggal dunia. KH. Wahid Hasyim, yang merupakan harapan banyak orang di Indonesia, telah menghembuskan nafas terakhir, dalam usia 38 tahun dan KH. Abdurrahman Wahid baru berusia 12 tahun. ${ }^{45}$

Pengaruh kematian tragis ayahnya yang terlalu cepat dalam usia KH.Wahid Hasyim yang relatif muda 38 tahun $^{46}$ amat berbekas dalam ingatannya. Kejadian itu bagi Gusdur merupakan pengalaman paling traumatik, mengingat ia sendiri ikut serta bersama ayahnya di dalam mobil tersebut. Gusdur berada di depan dan ayahnya berada di belakang. Ketika mobil terbalik, ayahnya terlempar keluar dan luka parah, sehari kemudian beliau meninggal. ${ }^{47}$ Kematian sang ayah merupakan pukulan berat bagi Abdurrahman Wahid dan keluarganya. ${ }^{48}$ Peristiwa itulah, KH. Abdurrahman Wahid merasakan gejolak pada dirinya untuk ikut bertanggung jawab dengan masa depan keluarga dan Nahdatul Ulama. ${ }^{49}$ Bahkan sesuatu yang berubah secara tajam, yaitu rumahnya yang mulai sepi dari orang-orang dan para tamu penting yang sering membawa informasi berharga.

\footnotetext{
${ }^{44}$ Umaruddin Masdar, Membaca Pikiran Gusdur dan Amien Rais Tentang Demokrasi, (Yogyakarta: Pustaka Pelajar, 1998), hlm. 119.

${ }^{45}$ Greg Barton, Biografi Abdurrahman Wahid, hlm. 44-45

${ }^{46}$ Menurut sebagian kalangan, antara lain Greg Barton, beliau meninggal dalam usia yang ke-40, tetapi bila merujuk pada buku Menteri-menteri Agama RI; Biografi Sosial Politik, (INIS, PPIM dan Litbang Depag disebutkan bahwa masa hidup K.H. Wahid Hasyim antara 1914-1953), hlm. 82.

${ }^{47}$ Majalah Gamma No. 36 tahun pertama, 31 Oktober 1999.

${ }^{48}$ Menurut informasi Greg Barton dari hasil wawancaranya dengan Abdurrahman Wahid pada bulan Desember 1999, ia menceritakan bagaimana ia sangat mencintai almarhum ayahnya itu. Diingatnya bagaimana ia berusaha memecahkan arti semua ini untuk berpikir "apa yang mungkin dilakukan oleh seorang manusia sehingga rakyat sangat mencintainya?"Apakah ada prestasi yang lebih baik daripada hal ini dalam hidup, kenangan yang pahit namun manis ini tetap tak terlupakan oleh Abdurrahman Wahid. Greg Barton, Biografi Abdurrahman Wahid, hlm. 43-44.

${ }^{49}$ Sejak masa kanak-kanak, ibu Abdurrahman Wahid telah diberi berbagai isyarat bahwa Abdurrahman Wahid akan mengalami garis hidup yang berbeda dan memiliki kesadaran penuh akan tanggung jawab terhadap organisasi NU. Menjelang remaja rasa tanggung jawab tersebut ternyata secara dramatis meningkat terutama setelah kematian ayahnya. Baca Greg Barton, Gagasan Islam Liberal Indonesia, (Jakarta, Paramadina: 1999), hlm. 326 .
} 


\section{Pemikiran KH. Abdurrahman Wahid tentang Sistem pendidikan Pesantren}

Kajian akan membahas pemikiran KH. Abdurrahman Wahid tentang komponenkomponen sistem pendidikan pesantren yang terdiri dari tujuan pendidikan, program pendidikan, proses pendidikan, dan evaluasi pendidikan pesantren. Hal ini dimaksudkan untuk memahami bagaimana pandangan KH. Abdurrahman Wahid tentang komponenkomponen pendidikan tersebut.

\section{Tujuan Pendidikan Pesantren}

Tujuan atau cita-cita sangat penting di dalam aktivitas pendidikan, karena merupakan arah yang hendak dicapai. Maka tujuan harus ada sebelum melangkah untuk mengerjakan sesuatu. Bila pendidikan dipandang sebagai suatu proses, maka proses tersebut berakhir pada pencapaian tujuan akhir pendidikan. ${ }^{50}$ Dalam perspektif historis tujuan pendidikan ${ }^{51}$ pesantren $^{52}$ menurut laporan Departemen Agama, bahwa pada awal perkembangannya, tujuan pesantren ialah untuk mengembangkan agama Islam, dan lebih memahami ajaran Islam, terutama dalam bidang fiqih, bahasa Arab, tafsir, hadits, dan tasawuf. ${ }^{53}$ Tujuan pendidikan pesantren menurut KH. Abdurrahman Wahid adalah terintegrasinya pengetahuan agama dan non agama, sehingga lulusan yang dihasilkan memiliki kepribadian yang utuh dan bulat dalam dirinya tergabung unsur-unsur keimanan dan pengetahuan secara berimbang. ${ }^{54}$ Jika dilihat konteks gagasan KH. Abdurrahman Wahid, mengenai tujuan pendidikan pesantren, maka ada dua hal yaitu: Pertama, tujuan khusus yakni mempersiapkan para santri untuk memiliki ilmu agama dan non agama. Kedua, tujuan umum adalah membimbing santri untuk menjadi manusia yang berkpribadian Islam yang mampu mengamalkan ilmunya. ${ }^{55}$ Inilah yang diistilahkan KH. Abdurrahman Wahid sebagai watak hidup mandiri, yang bersumber pada sistem nilai sendiri. ${ }^{56}$ Karena itu, untuk mencapai tujuan pesantren secara kelembagaan KH. Abdurrahman Wahid mempunyai gagasan sebagai berikut:

\section{Pesantren Subkultur}

Pesantren merupakan fokus perhatian pertama KH. Abdurrahman Wahid dalam memulai tradisi tulis di tahun 1974 an, karena itu, KH. Abdurrahman Wahid dalam teori subkulktur ini setidaknya menengahi dua hal yakni pesantren dan masyarakat modern, sehingga membutuhkan komunikasi untuk membangun tradisi di tengah modernisasi. ${ }^{57}$ Dengan kata lain, budaya sebagai alat yang memungkinkan pembangunan bisa berlangsung dengan sukses, dalam teori antoropologi ada tiga alasannya: Pertama, unsur-unsur budaya yang dimiliki mempunyai letigitimasi tradisional di mata orang-orang yang menjadi sasaran

${ }^{50}$ M. Arifin, Filsafat Pendidikan Islam, hlm. 108.

${ }^{51}$ Menurut Hasan Langgulung tujuan pendidikan secara oprasional berdasarkan kepada aspek filosofi, psikologi, historis, sosial, politik dan ekonomi. Hasan Langgulung, Manusia dan Pendidikan, (Jakarta: Pustaka al-Husna, 1995), hlm. 55-59.

${ }^{52}$ Tujuan pesantren menurut Ziemek dan Mastuhu, mempunyai pendapat yang sama, yakni kepribadian menjadi sasaran yang dicita-citakan.

${ }^{53}$ Departemen Agama, Seri Monografi Pondok Pesantren dan Angkatan Kerja, (Jakarta: Departemen Agama RI, 2000/2003), hlm. 12-13.

${ }^{54}$ Abdurrahman Wahid, Bunga Rampai Pesantren, h. 172-2.

${ }^{55}$ M. Arifin, Kapita Seletakta Pendidikan Islam dan Umum, (Jakarta: Bumi Aksara, 1993), hlm. 248.

${ }^{56} \mathrm{KH}$. Abdurrahman Wahid, Menggrakkan Tradisi, hlm. 142.

${ }^{57}$ KH. Abdurrahman Wahid, Bungan Rampai Pesantren, hlm. 10. 
program pembangunan. Kedua, unsur-unsur budaya secara simbolis merupakan komunikasi paling berharga dari penduduk setempat. Ketiga, unsur-unsur budaya mempunyai aneka ragam fungsi (baik wujud maupun samar) yang menjadikannya sebagai sarana paling berguna untuk perubahan. ${ }^{58}$

Pemikiran di atas, hampir tidak alasan menyingkirkan kebudayaan tradisional dalam pembangunan. Hal ini disebabkan kebudayaan tradisional terkait erat dengan proses sosial, ekonomi dan ekologis masyarakat secara mendasar. Konsep inilah yang membuat KH. Abdurrahman menggagas teori subkultural pesantren, yang memiliki beberapa aspek: ${ }^{59}$ Pertama, aspek kegiatan pesantren berputar pada pembagian periode berdasarkan waktu sembayang wajib lima (shalat rawatib). Kegiatan pokok dipusatkan pada pemberian pengajian buku-buku teks (al-kutub al-muqarrarah) pada setiap habis menjalani sembanyang wajib. Inilah yang dikatakan KH. Abdurrahman Wahid sistem nilai kepesantrenan yang unik dan terpisah dari sistem nilai masyarakat di luarnya. Kedua, dalam pesantren terpeliharanya literatur universal selama berabad-abad dan diwariskan dari generasi ke generasi. Ketiga, pola kepemimpinan ${ }^{60}$ yang berdiri sendiri dan berada di luar kepemimpinan pemerintahan desa. Keempat, struktur pengajarannya yang unik dan memiliki ciri khas sudah tentu juga menghasilkan pandangan hidup dan aspirasi yang khas pula. Visi untuk mencapai penerimaan di sisi Allah di hari kelak menempati kedudukan terpenting dalam tata nilai di pesantren yang kenal dengan keikhlasan yang mengadung arti ketulusan dalam menerima, memberikan dan melakukan sesuatu di antara sesama makhluknya.

Dari konsep di atas, KH. Abdurrahman Wahid mampu melukiskan dan mengkomunikasikan substansi dunia pesantren pada masyarakat biasa yang tidak terlalu akrab dengan lingkungan pesantren, dengan muda dibawa pada pemahaman tentang dasardasar pesantren. Dengan pola kehidupan yang unik pesantren, mampu bertahan selama berabad-abad untuk mempergunakan nilai-nilai hidup sendiri. Karena itu, dalam jangka panjang pesantren berada dalam kultural yang relatif lebih kuat dari pada masyarakat sekitarnya. ${ }^{61}$ Bahkan lembaga kultural ini mampu memperkenalkan gagasan pembangunan pedesaan (rural development, sebagai pusat kegiatan belajar masyarakat (centre of community learning), dan juga pondok pesantren sebagai lembaga pendidikan Islam yang bersandar pada silabi, yang dibawakan oleh intelektual Imam Jalaluddin Abdurrahman Alsuyuti lebih dari 500 tahun yang lalu. ${ }^{62}$ Bagi KH. Abdurrahman Wahid jika pesantren memainkan peran di atas, dengan kreatif dan mampu terintegrasi ke dalam sistem pendidikan

\footnotetext{
${ }^{58}$ Lihat Nat. J. Colletta, Kebudayaan dan Pembangunan; Sebuah Pendekatan terhadap Antropologi Terapan di Indonesia, (Jakarta: Yayasan Obor, 1992), hlm. 5-6.

${ }^{59}$ KH. Abdurrahman Wahid, Bunga Rampai Pesantren, hlm. 19-42

${ }^{60}$ Watak sub-kultur yang ditemukan KH. Abdurrahman Wahid dalam nilai, cara hidup, dan model kepemimpinan di atas, pada perjalanannya telah menempatkan pesantren dalam peran ganda: subsistem unik yang terpisah, dan oleh karena itu menjelma alternatif ideal bagi krisis sistemik masyarakat di sekelilingnya. Posisi ideal ini menurutnya sangat sesuai dengan perwujudan kultural Islam yang sampai ke Nusantara. Perwujudan kultural Islam ini mewujud dalam perpaduan antara doktrin formal Islam dengan kultus para wali (berpuncak pada kultus wali songo), sebagai sisa pengaruh pemujaan orang-orang suci (hermits) dalam agama Hindu. Perwujudan kultural tersebut nampak nyata dalam asetisme (az-zuhud, kealiman) yang mewarnai kehidupan agama Islam di kepulauan Nusantara, tidak sebagaimana terjadi di negeri-negeri Arab. Disisi lain, posisi keterpisahan kultural tersebut kemudian dibarengi oleh posisi menjadi bagian dari masyarakat, dalam arti keterlibatan aktif pesantren dalam proses perubahan sosial. Lihat, KH. Abdurrahman Wahid, Bungan Rampai Pesantren, hlm. 23.

${ }^{61} \mathrm{KH}$. Abdurrahman Wahid, Menggrakkan Tradisi Esai-esai, hlm. 10.

${ }^{62} \mathrm{KH}$. Abdurrahman Wahid, Islamku, Islam Anda, Islam Kita, hlm. 223.
} 
nasional dan pada sisi lainnya mampu berupaya sebagai agen perubahan dalam masyarakat, melalui kerjasama dengan sepak terjang para LSM di sisi lainnya, niscaya masa depan pesantren akan cerah. ${ }^{63}$ Bahkan gagasan KH. Abdurrahman Wahid tentang manfaat koperasi bagi pesantren, ${ }^{64}$ merupakan bentuk perhatian bahwa peran pesantren di masyarakat pedesaan tidak hanya menyiapkan kader-kader ulama dan muballigh masa depan, tetapi lebih dari itu, bagaimana pesantren mencetak santri-santri yang mempunyai keterampilan. Teori subkulturl yang dimunculkan KH. Abdurrahman di atas, dapat disimpulkan pada tiga hal: Pertama, adalah suatu usulan kepada para pengambil kebijakan akan pentingnya pesantren menjadi subjek dalam pembangunan. Kedua, undangan para ilmuwan sosial untuk lebih jauh mengenal pesantren. Ketiga, suatu hal yang perlu didiskusikan, sharing, ajakan kepada para pengelolah pesantren untuk mengembangkan pesantren mereka, baik secara individu maupun kolektif.

\section{Program Pendidikan Pesantren}

Dalam mencapai tujuan pendidikan pesantren di atas, KH. Abdurrahman Wahid membahas program pendidikan pesantren atau lebih dikenal dengan kurikulum pendidikan pesantren. Perjumpaan pesantren dengan kurikulum merupakan sebuah keharusan karena kedudukannya yang cukup sentral dalam dunia keilmuan, dan sebagai lembaga pendidikan Islam, pesantren memiliki akar sosio-historis yang cukup kuat. Menurut Raehani bahwa secara historis kurikulum ${ }^{65}$ pendidikan pesantren adalah kurikulum yang sudah direncanakan (the planned curriculum) untuk mencapai tujuan pesantren. ${ }^{66}$ Dengan bahasa lain, bahwa kurikulum dalam pendidikan pesantren sudah dikenal, dengan melihat kegiatan yang mencakup berbagai rencana akativitas santri (peserta didik) yang terinci berupa bentukbentuk bahan pendidikan, stretegi belajar mengajar, pengaturan-pengaturan program agar dapat diterapkan agar tujuan dapat tercapai. ${ }^{67}$ Inilah yang diistilahkan Raehani the lived curriculum, $^{68}$ pengalaman santri pada pendidikan pesantren, isitlah ini dalam teori pengembangan kurikulum lebih dikenal karakteristik kurikulum yang sebagai perangkat pengalaman (curriculum as experience). ${ }^{69}$ Atau kurikulum tersembunyi (the hidden curriculum) adalah kurikulum yang tidak direncanakan dalam program dan tidak tertulis yang merupakan kreativitas yang membawa manfaat bagi peserta didik, guru dan

\footnotetext{
${ }^{63}$ KH. Abdurrahman Wahid, "Pesantren dan Pengembanganya," dalam Bunga Rampai Pesantren, hlm. 63. Artikel ini perna di muat diharian Kompas 25 Mei 1978.

${ }^{64}$ Artikel ini disampaikan di Musyawarah Koperasi Pondok Pesantren dan Lembaga Pendidikan seSulawesi di Goa, Makassar, 30, Juni 1976.

${ }^{65}$ Kurikulum secara luas menurut Hasan Langgulung adalah sejumlah pengalaman, pendidikan, kebudayaan, sosial, keolahragaan dan kesenian yang disediakan oleh sekolah bagi murid di dalam dan di luar sekolah dengan maksud menolong mereka untuk berkembang dan mengubah tingkah laku mereka sesuai dengan tujuan pendidikan. Hasan Langgulung, Peralihan Paradigma dalam Pendidikan Islam dan Sains Sosial, (Jakarta: Gaya Media Pratama, 2002), hlm. 241.

${ }^{66}$ Lihat Raehani, Curriculum Construction in the Indonesian Pesantren, (Koln: Lambert Academic Publishing, 2009), hlm. 89.

${ }^{67}$ Ahmad Tafsir dkk (penyunting), Cakrawala Pemikrian Pendidikan Islam, hlm. 221.

${ }^{68}$ Pengalaman berupa aktivitas yang dilakukan di pesantren misalnya penerimaan tamu dari berbagai latar belakang, kegiatan-kegiatan pembelajaran dan dialog dan lain-lain. Rahaini, Islam dan Kemajemukan Indonesia, Studi Kasus Pesantren dan Pendidikan Multikultural, hlm. 390.

${ }^{69}$ Menurut John Dewey (1916) pengalaman suatu kurikulum yang juga merefleksi kurikulum itu dan konsekuensinya memerlukan usaha untuk memonitor segala pikiran dan tindakan seseorang dalam konteks kurikulum. Abdullah Idi, Pengembangan Kurikulum Teori dan Praktik, (Yogyakarta: Ar-Ruzz, 2007), hlm. 46.
} 
sekolah. ${ }^{70}$ Konsep di atas, dapat ditegaskan bahwa kurikulum itu mempunyai empat unsur utama: Pertama, tujuan dan obyektif yang ingin dicapai oleh pendidikan. Kedua, pengetahuan dan informasi, data, aktivitas, serta pengalaman yang membentuk kurikulum itu. Ketiga, metode atau cara mengajar yang digunakan guru untuk mengajarkan dan mendorong murid belajar dan membawa mereka ke arah yang dikehendaki oleh kurikulum. Keempat, penilaian yang digunakan dalam mengukur dan menilai kurikulun serta hasil pembelajaran pendidikan yang dirancang dalam kurikulum, seperti ujian catur wulan. ${ }^{71}$

Argumentasi di atas, memberikan kekuatan pada pesantren bahwa sebagai lembaga tradisional telah terbukti memperkenalkan karakteristik dan unsur-unsur kurikulum yakni kurikulum sebagai bahan ajar (subject matter) dan kurikulum tersembunyi (hidden curriculum). Dalam pandangan KH. Abdurrahman Wahid kurikulum sebagai bahan ajar adalah materi ilmu agama Islam dan non agama yang diajarkan di pesantren, sementara itu, kurikulum tersembunyi adalah sistem nilai yang dianut di pensantren yakni: pertama, sikap memandang kehidupan sebagai kerja peribadatan. Kedua, kecintaan pada ilmu-ilmu agama yang sangat kuat pada diri santri. Ketiga, keikhlasan bekerja atau ketulusan bekerja untuk tujuan bersama. ${ }^{72}$ Kurikulum $^{73}$ pendidikan pesantren menurut KH. Abdurrahman Wahid merupakan salah satu komponen yang harus diperhatikan guna menghadapi perubahan dan menentukan arah kehidupan pesantren, serta perlu direkonstruksi. Kurikulum yang berkembang di dunia pendidikan pesantren selama ini, dapat diringkas ke dalam tiga pokok: Pertama, kurikulum yang bertujuan untuk mencetak ulama di kemudian hari; Kedua, struktur dasar kurikulumnya adalah pengajaran pengetahuan agama dalam segenap tingkatan dan pemberian dalam bentuk bimbingan kepada santri secara pribadi oleh kiai/guru. Ketiga, secara keseluruhan kurikulum yang ada berwatak lentur/fleksibel, yang sesuai dengan kehendak kiai sesuai dengan kebutuhan dan kemampuan santri. ${ }^{74}$

Kurikulum sistem pendidikan pesantren yang diwakili oleh kitab kuning, hanya lebih menekankan pada bidang fiqh, teologi, tasawuf, dan bahasa. Fiqh biasanya hanya terbatas pada mazhab Syafi'i dan kurang memberikan alternatif pada mazhab-mazhab lain. Pada umumnya fiqh diartikan sebagai kumpulan hukum amaliah yang disyariatkan Islam, yang penekanannya sangat berlebihan dan mendalam. ${ }^{75}$ Kajian fiqh yang hanya menganut salah satu mazhab berakibat membelenggu kreativitas berfikir dan membuat sempit pemahaman atas elastisitas hukum. Mazhab Syafi'i juga memberikan peluang yang minim kepada penjelasan kepada wawasan rasional. Peranan rasio dalam mengambil kesimpulan hukum, legalitas formal yang bersumber dari ajaran dasar kurang diberdayakan. Karena itu, pada aspek ini tampaknya penting melebarkan wacana fiqh lintas mazhab. ${ }^{76}$

\footnotetext{
${ }^{70}$ M. Print, Curriculum Development and Design, terj. (Australia: Allen dan Unwin, 1993), hlm. 10.

${ }^{71}$ Hasan Langgulung, Peralihan Paradigma dalam Pendidikan Islam dan Sains Sosial, hlm. 241.

${ }^{72} \mathrm{KH}$. Abdurrahman Wahid, Menggerakkan Tradisi Esai-Esai Pesantren, hlm. 149.

${ }^{73}$ Kurikulum secara fungsional dapat diartikan sebagai manhaj atau serangkaian dan media yang
} diharakan, dan memiliki beberapa prinsip mewujudkan prinsip sebagai berikut; berorientasi pada tujuan, terdapat relevansi yang sinergis, efektif, efesiensi, fleksibilitas, integritas, kontiunitas, sinkronisme, obyektivisme, demokrasi dan analisis. S. Nasution, Asas-asas Kurikulum, (Jakarta: Bumi Aksara, 1995), Cet 2, hlm. 9.

${ }^{74} \mathrm{KH}$. Abdurrahman Wahid, Bunga Rampai Pesantren, hlm. 101

${ }^{75}$ Sebagai buktinya menurut beliau adalah pesantren-pesantren pedalaman terhadap kitab fiqh melalui kitab kuning biasanya berupa tradisi syara $\underline{h}$ dan hâsyyiyah. Yang diawali dari Matn al-Tarqrîb, yaitu kitab fiqh yang paling standar di pesantren-pesantren. Matan itu diberi syara $\underline{h}$ dalam kitab Fath al-Qarîb, juga sangat standar di pesantren, dan akhirnya diberi hâsyîyah dalam kitab al-Bâjûrî, sebuah kitab yang boleh dipandang cukup tinggi. Nurcholish Madjid, Bilik-Bilik Pesantren, h. 8.

${ }^{76}$ Suwendi, Sejarah dan Pemikiran Pendidikan Islam, hlm. 121-122. 
Isi kurikulum di atas, memperlihatkan dengan jelas bahwa materi yang paling dominan adalah bahasa, baru kemudian fiqih. Saridjo dan Shaleh menyebut bahwa pengetahuanpengetahuan yang paling diutamakan adalah pengetahuan yang berhubungan dengan bahasa Arab (ilmu sharf dan ilmu alat yang lain) dan ilmu yang berhubungan dengan ilmu syariah (ilmu fiqih, baik berhubungan dengan ibadah maupun muamalah). Sebaliknya, dalam perkembangan terakhir fiqih justru menjadi ilmu yang paling dominan di pesantren. ${ }^{77}$

Melihat pemikiran di atas, kurikulum pendidikan pesantren menghendaki terintegrasinya keilmuan antara ilmu agama dan ilmu umum. Dengan kata lain, penerapan kurikulum dalam pesantren dengan keseimbangan atau chek and balance. Hanya saja, menurut KH. Abdurrahman $\mathrm{Wahid}^{78}$ pola tersebut, dengan terintegritasinya komponen agama dan non agama dalam kurikulum pesantren selama beberapa tahun belum memperoleh hasil. Malah porsi ilmu agama semakin lama sangat menurun, sehingga melahirkan mentahnya lulusan yang dihasilkan oleh pesantren, tidak menjadi agamawan yang berpengetahuan agama mendalam dan juga tidak menjadi ilmuwan non agama yang cukup tinggi kualitasnya, yang terjadi adalah pembauran (akulturasi) yang tidak memperlihatkan identitas yang jelas.

Menghadapi kenyataan di atas, banyak pimpinan lembaga pendidikan pesantren kembali pada cara salaf, dengan penekanan pada porsi ilmu agama, sehingga ilmu umum (non agama) dalam kurikulumnya nyaris tidak terpakai lagi. Hal ini bagi KH. Abdurrahman Wahid sangat membahayakan dunia pendidikan pesantren dan lulusannya, sebab modernisasi adalah sebuah kebutuhan yang harus dihadapi para santri di masa depan. Karena itu, kesalahan-kesalahan dasar dalam pengembangan komponen ilmu non agama dalam kurikulum pendidikan pesantren selama ini, hingga tidak mampu mendorong menjadi agamawan, bukan memperbaikinya dengan membuang ilmu non agama, karena tantangan masa depan tidak hilang hanya dengan cara tersebut. Tetapi di masa mendatang manusia dituntut memiliki bekal rohani yang kuat dan juga ditentukan pada penguasaan Iptek. ${ }^{79}$

KH. Abdurrahman Wahid menjelaskan ada beberapa kelemahan dasar dalam upaya pengembangan komponen non agama dalam kurikulum pendidikan pesantren. ${ }^{80}$ Kelemahan pertama, adalah lebih banyak ditekankan pada pengembangan intelektualisme verbalistik yang penuh dengan teori tapi tak mampu memecahkan persoalan-persoalan praktis yang terjadi di depan mata. Kedua, penanganan kurikulum dan komponen-komponennya secara sepotong-potong, tidak menggunakan pendekatan menyeluruh yang bersifat multidisipliner (yang terbukti antara lain dalam pemisahan antara pengetahuan-pengetahuan sosial ekonomi, budaya dan pengetahuan alam). Ketiga, belum tercapainya kesatuan yang utuh dan bulat antara komponen-komponen agama dan non agama. ${ }^{81}$ Kelemahan-kelemahan dasar tersebut justru menimbulkan kebutuhan dan pengembangan pendidikan pesantren, setidaktidaknya dalam kurikulum yang digunakan dapat menyediakan tenaga-tenaga terdidik yang sesuai dengan lapangan kerja masyarakat modern.

Menurut KH. Abdurrahman Wahid, dunia pendidikan pesantren bersedia membuka diri bagi pendidikan yang menjurus dalam hubungannya dengan penyediaan angkatan

${ }^{77}$ Marwan Saridjo et.al., Sejarah Pondok Pesantren di Indonesia, (Jakarta: Dharma Bhakti, 1982), hlm.

${ }^{78}$ KH. Abdurrahman Wahid, Menggerakkan Tradisi Esai-Esai Pesantren, hlm. 136.

${ }^{79} \mathrm{KH}$. Abdurrahman Wahid, Menggerakkan Tradisi Esai-Esai Pesantren, hlm. 137.

${ }^{80} \mathrm{KH}$. Abdurrahman Wahid, Menggerakkan Tradisi Esai-Esai Pesantren, hlm. 137.

${ }^{81} \mathrm{KH}$. Abdurrahman Wahid, Bunga Rampai Pesantren, hlm.169. 
kerja. ${ }^{82}$ Hal ini sejalan dengan pendapat Indra Djati Sidi dalam istilah creative curriculum artinya kurikulum pendidikan masa depan dikembangkan berdasarkan kompotensi dasar. ${ }^{83}$ Selanjutnya kurikukulum yang memiliki kesesuaian dan keterkaitan (link and match) dengan kebutuhan lapangan kerja, baik dalam bidang jasa maupun perdagangan dan keahlian lainnya, yang memberikan masukan bagi kalangan pendidikan, tentang keahlian yang sesungguhnya dibutuhkan lapangan kerja. Untuk mengatasi persoalan integrasi kurikulum pendidikan pesantren KH. Abdurrahman Wahid menawarkan model kurikulum pendidikan pesantren dengan menciptakan model penyederhanaan kurikulum yang memungkinkan lembaga pendidikan pesantren menyelenggarakannya, ${ }^{84}$ dalam artian muatan kurikulum tidak terlalu banyak dibebankan pada santri, sehingga penyediaan tenaga terampil dan terlatih untuk berbagai jenis profesi disesuaikan dengan tujuan dan fungsi pesantren.

Beberapa ketentuan dijadikan batasan dalam penyusunan model-model kurikulum yang di tawarkan KH. Abdurrahman Wahid untuk kurikulum pendidikan pesantren yaitu: Pertama, ketentuan untuk menghindarkan pengulangan ('adam al-tikrâr), sepanjang tidak dimaksudkan untuk pendalaman (ta'ammuq) dan penjenjangan (tadarruj). Dengan demikian, dapat terhindarkan dari pemborosan waktu. Ketentuan kedua, pemberian tekanan pada latihan (tamrinât), karena buku yang dipakai diusahakan yang seringkas mungkin dalam ilmu-ilmu alat. Ketiga, tidak dapat dihindari adanya lompatan-lompatan yang tidak berurutan dalam penetapan buku-buku wajib (kutub al-muqarrarah) selama masa pendidikan dari tahun ke tahun. ${ }^{85}$

Gagasan dengan menyederhanakan kurikulum, agar dapat dikembangkan kurikulum menjadi lebih lengkap dan bulat yang mampu menampung komponen pendidikan non agama, tanpa adanya kekhawatiran penurunan tingkatan atau nilai pendidikan agama di pondok pesantren. Bahkan KH. Abdurrahman Wahid menjelaskan bahwa model kurikulum yang disederhanakan di samping merupakan jalan untuk menerima komponen-komponen pendidikan ilmu-ilmu umum, juga yang terpenting adalah tidak mengorbankan tujuan menciptakan santri yang memiliki pengetahuan dasar agama yang bulat dan cukup. ${ }^{86}$ Gagasan di atas, jika diapalikasikan menurut KH. Abdurrahman Wahid mempunyai beberapa ketentuan-ketentuan yaitu: ${ }^{87}$ (a) Pemberian waktu terbanyak dilakukan pada unsur nahwu-sharaf dan figh karena kedua unsur ini masih memerlukan ulangan (tikrâr), setidaktidaknya untuk separu dari masa berlakunya kurikulum. (b). Mata pelajaran lain hanya diberikan selama setahun tanpa diulang pada tahun-tahun berikutnya. (c) Kalau diperlukan, pada tahun-tahun terakhir dapat diberikan buku-buku utama (kutub al-mutâla'ah) seperti

\footnotetext{
${ }^{82}$ KH. Abdurrahman Wahid, Menggerakkan Tradisi Esai-Esai Pesantren, hlm. 109-110.

${ }^{83}$ Dalam konsep ini, kurikulum disusun berdasarkan kemampuan dasar minimal yang harus dikuasai seorang peserta didik setelah yang bersangkutan menyelesaikan satu unit pelajaran, satu satuan waktu dan satu satuan pendidikan. Dengan demikian, seorang peserta didik belum melanjutkan pelajaran ke unit atau satuan pendidikan berikutnya sebelum yang bersangkutan menguasai unit pelajaran yang persyaratkan. Kurikulum berdasarkan kompetensi ini diharapkan dapat menjamin tercapainya standar kualitas tamatan lembaga pendidikan tertentu, yang selama ini menjadi masalah nasional di bidang pendidikan. Indra Djati Sidi, Menuju Masyarakat Belajar, Menggagas Paradigma Baru Pendidikan, (Jakarta: Paramadina, 2001), hlm. 15.

${ }^{84} \mathrm{KH}$. Abdurrahman Wahid, Menggerakkan Tradisi Esai-Esai Pesantren, hlm. 120.

${ }^{85}$ Sebagai contoh kurikulum model Tegalrejo, antara lain terlihat: Dari tahun pertama, al-Jurumîyah, Safinah al-Najâh, Hidâyat al-Shibyân; untuk tahun kedua, Nazal-Imrîti, Taqrib, al-Amtsilah al-Tasrîfîyah; tahun ketiga, Alfîyah, Minhâj al-Qawîm; tahun keempat, Fath al-Wahhâb, Jauharat al-Maknûn; tahun kelima; Al-Mahalli, salah satu kitab mantiq; untuk tahun keenam, Latáif al-Isyârah, al-Bukhârî, serta untuk tahun ketujuh Ihya'. KH. Abdurrahman Wahid, Menggerakkan Tradisi Esai-Esai Pesantren, hlm. 165.

${ }^{86}$ KH. Abdurrahman Wahid, Menggerakkan Tradisi Esai-Esai Pesantren, hlm. 166.

${ }^{87}$ KH. Abdurrahman Wahid, Menggerakkan Tradisi Esai-Esai Pesantren, hlm. 163.
} 
shahih bukhari atau Muslim untuk hadits dan untuk tasawuf adalah Ihya' 'Ulûm al-Dîn, ini hanya diberikan hanya satu tahun.

Format kurikulum yang digagas KH. Abdurrahman Wahid selama 6 tahun adalah:

a. Tahun pertama yang diberikan yaitu nahwu, fiqh, tauhid.

b. Tahun kedua: nahwu, figh, sharaf, tauhid.

c. Tahun ketiga: nahwu, fiqh, sharaf, tauhid.

d. Tahun keempat: fiqh, balaghah, tafsir.

e. Tahun kelima: mantiq, ushul fiqh, dan hadits.

f. Tahun keenam: hadits dan tasawuf.

Kekurangan yang dirasakan format kurikulum di atas, yakni tidak adanya unsur yang baru dalam bahasa Arab (lughah hadîtsah) yang terdiri dari qirâ'ah, dan muhâdatsah. Akan tetapi, memang rumusan di atas, ditujukkan pada sistem pendidikan non klasikal yang tidak memetingkan unsur-unsur baru tersebut. Unsur-unsur baru dapat dijadikan bagian integral dari mata pelajaran di atas (dalam bentuk tamrinah), maupun dijadikan kegiatan aplikatif yang bersifat ekstrakurikuler.

Pemikiran di atas, dapat dipahami bahwa kurikulum pendidikan pesantren yang digagas KH. Abdurrahman Wahid tidak menghendaki adanya dikotomi ilmu pengetahuan antara ilmu agama dan non agama. Inilah yang di istilahkan Suwito terciptanya integrasi ilmu-ilmu yang bersumber pada ayat- ayat qur'ânîyah dan ilmu-ilmu yang bersumber ayatayat kaunîyah. Ilmu-ilmu yang bersumber dari ayat-ayat qur'anîyah disebut ilmu agama dan ilmu yang bersumber dari ayat-ayat kaunîyah disebut ilmu umum. ${ }^{88}$ Hanya saja, menurut KH. Abdurrahman Wahid, penguasaan pengetahuan agama haruslah diberi porsi cukup besar dalam kurikulum pendidikan pesantren. Porsi itu dapat diberikan dalam ukuran besar secara kualitatif, walaupun sedikit secara kuantitatif. ${ }^{89}$ Dengan kata lain, modernisasi kurikulum pendidikan pesantren tetap pada jati diri khas, sebab itulah yang sungguhnya yang dimiliki oleh lembaga pendidikan pesantren. Hal ini tentunya semua berpulang kepada pengelola atau pengasuh pondok pesantren, serta kreativitasnya, rasa percaya diri dan tanggung jawab masyarakat pendukung pesantren secara menyeluruh.

\section{a) Memasukkan Pelajaran Umum ke Pesantren}

\footnotetext{
${ }^{88}$ Makalah seminar sambutan atas nama Rektor UIN Syarif Hidayatullah, Jakarta, pada acara Workshop, "Kurikulum berbasis kompetensi", pada Program Studi Agribisnis Fakultas Sains dan Teknologi, (Jakarta: 17 April 2003), hlm. 1 Secara sederhana beliau menjelaskan sebagai berikuat: (a) Historical Content setiap Pendidik hendaknya menjelaskan sejarah lahir dan perkembangan ilmu yang sedang dipelajari sejak awal pertumbuhan sampai sekarang.( b) Theorical Content, hal ini masih terkait dengan yang di atas pendidik harus dapat menampilkan teori-teori yang pernah dikemukakan oleh para ahli dari masa ke masa. Dengan demikian akan merangsang para peserta didik untuk memperdalam ilmu tersebut. Dan bahkan memiliki keberanian untuk mengembangkan agar memperoleh hal yang baru.(c) Practical Conten Setiap bidang ilmu juga perlu penjelasan dari sisi kegunaan praktisnya untuk kepentingan kehidupan. Dengan cara ini diharapkan para peserta didik dapat mengambil manfaatnya setelah mempelajari bidang studi tersebut. (d) Case Content, masih terkait dengan butir c di atas, setiap bidang ilmu perlu dijelaskan pula beberapa studi kasus yang terkait dengan ilmu tersebut. Dengan demikian setiap pendidik mampu memberikan contoh kasus dalam kaitan manfaat praktis suatu bidang ilmu. (e) Science and Tecnologi Content, banyak ayat al-Qur' an yang memerlukan penjelasan dan sisi sains dan teknologi, bukan hanya sisi bahasa dan sastra Arab, ushul fiqh, tajwid atau ilmu yang selama ini dikenal sebagai ilmu agama. Selain akan menjadi lebih jelas, pendekatan secara sains dan teknologi dalam menjelaskan ayat-ayat al-Qur'an dan Hadis akan lebih memperkuat keyakinan untuk berislam dan mengembangkan ilmu pengetahuan. (f) Islamic Content, atas dasar keyakinan bahwa semua ilmu dan lainnya yang ada dialam ini berasal dari Yang Maha Satu, maka antara ilmu yang sekarang dikenal sebagai ilmu agama tak mungkin bertentangan dengan ilmu yang kini diyakini dengan ilmu umum.

${ }^{89}$ KH. Abdurrahman Wahid, Menggerakkan Tradisi Esai-Esai Pesantren, hlm. 157.
} 
KH. Abdurrahman Wahid, menjelaskan bahwa integrasi dengan cara menyederhanakan kurikulum pesantren dapat memberikan peluang kurikulum umum untuk masuk. Namun demikian, porsi kurikulum pendidikan pesantren, secara penguasaan pengetahuan agama haruslah diberi porsi cukup besar dalam kurikulum pendidikan pesantren. Porsi itu dapat diberikan dalam ukuran besar secara kualitatif, walaupun sedikit secara kuantitatif sehingga santri memiliki ilmu agama yang kuat, dan ilmu non agama.

\section{b) Pesantren dan Penyiapan Angkatan Kerja}

Secara kurikuler, terkait dengan peranan pesantren dalam menyediakan angkatan kerja, tidak ada hubungan langsung dan spesifik diantara keduanya. Menurut KH. Abdurrahaman Wahid kurikulum yang berkembang di pesantren memperlihatkan sebuah pola tetap yang terdiri dari tiga pola dasar: ${ }^{90}$ (a) kurikulum ditujukan untuk mencetak ulama dikemudian hari, (b) struktur dasar kurikulum itu adalah pengajaran pengetahuan agama dalam segenap tingkatanya dan pemberian pendidikan dalam bentuk bimbingan kepada santri secara pribadi oleh kiai atau guru, dan (c) secara keseluruhan kurikulum yang ada berwatak lentur atau fleksibel. Hubungan kurikulum dengan penyediaan angkatan kerja, dengan karateristik di atas, mampu menghasilkan alumni yang dapat memasuki lapangan kerja tradisional seperti menjadi guru, petani, pedagang kecil dan pejabat pemerintahan pada jabatan yang tidak membutuhkan spesialis. Sepintas lalu, kenyataan ini menimbulkan penilaian negatif atas kemampuan pesantren dalam menyediakan tenaga kerja terdidik sesuai dengan kebutuhan lapangan kerja di masyarakat modern. Konsekuensinya, KH. Abdurrahman Wahid mengharapkan pesantren membuka diri bagi pendidikan yang menjurus kepada spesialisasi dalam hubungannya dengan penyediaan angkatan kerja. ${ }^{91}$ Harapan ini besar kemungkinannya mengingat pendidikan pesantren memiliki beberapa potensi besar untuk menerima semua itu. Pertama, jumlah santri yang demikian besar dan masif untuk mengisi kebutuhan tenaga kerja terlatih yang selama ini dianggap kurang, kedua, sistem tata nilai di pendidikan pesantren yang bertentangan dengan budaya modern menjadi potensi tersendiri, misalnya kejujuran, keikhlasan dan sikap memandang seluruh totalitas hidup sebagai ibadah, kalau kemudian dimanifestasikan dalam pembentukan mental individu akan membentuk karakter yang berkepribadian baik, ketiga, kelenturan dan fleksibilitas pesantren sendiri yang dapat mempermudah terbentuknya sekolah-sekolah spesialis tersebut menjadi kenyataan lebih cepat dengan tanpa menghilangkan karakter tradisional pesantren..$^{92}$

\section{c) Pemberdayaan Masyarakat Melalui Pesantren}

Secara sosilogis pesantren mempunyai keunggulan dan kedekatan strategis untuk memberdayakan masyarakat. Ikatan (emosional, rasional dan nilai) keagamaan serta kharisma seorang kiai-ulama bagi masyarakat menjadi faktor yang signifikansi untuk menempatkan pesantren sebagai salah satu motor penggerak lahirnya perubahan sosial melalui aksi pemberdayaan sosial. ${ }^{93}$ Atau istilah yang dipakai KH. Abdurrahman Wahid strategi sosial kultural, di mana kurikulum pesantren mengembangkan kerangka

\footnotetext{
${ }^{90} \mathrm{KH}$. Abdurrahman Wahid, Menggerakkan Tradisi Esai-Esai Pesantren, hlm. 145.

${ }^{91} \mathrm{KH}$. Abdurrahman Wahid, Menggerakkan Tradisi Esai-Esai Pesantren, hlm. 146.

${ }^{92} \mathrm{KH}$. Abdurrahman Wahid, Menggerakkan Tradisi Esai-Esai Pesantren, hlm. 69.

${ }^{93}$ Suwito NS,"Model Pengembangan Ekonomi Pesantren", dalam Jurnal Penelitian pendidikan Agama dan Keagamaan, (Malang: Volume 6 Nomor 3 Juli, 2008), hlm. 21.
} 
kemasyarakatan yang mempergunakan nilai-nilai dan prinsip-prinsip Islam. ${ }^{94} \mathrm{Hal}$ ini membuktikan bahwa dengan indikator yang jelas, pendidikan pesantren dengan tokoh kiai mampu berusaha untuk melakukan pemberdayaan kepada masyarakat dengan memberikan berbagai program dan pelatihan khusus pada rakyat kecil dalam rangka penumbuhan masyarakat yang beradab. ${ }^{95}$

Menurut KH. Abdurrahman Wahid, program-program yang diberikan dalam pendidikan pesantren memiliki peran penanaman nilai bagi kehidupan masyarakat secara lebih umum, seperti program penyuluhan dan bimbingan. Dalam program ini, para santri secara bergiliran dididik bersama-sama dengan para petani dan perajin dari masyarakat, sehingga santri mempunyai skill. ${ }^{96}$ Di samping itu, pendidikan pesantren dapat membentuk beberapa program pemberdayaan dan pembangunan masyarakat yang bertujuan membentuk tenaga-tenaga pembangunan masyarakat (change agent) dari pesantren, yang betugas membantu warga desa untuk mengenal dan memanfaatkan potensi yang mereka miliki untuk memperbaiki kehidupan mereka, dengan jalan merencanakan dan melaksanakan proyekproyek pengembangan desa mereka. ${ }^{97}$ Dalam konteks ini, KH. Abdurrahman Wahid, mengharapkan pendidikan pesantren bisa berperan sebagaimana lembaga swadaya masyarakat (LSM) dengan tujuan mampu memberi pemberdayaan masyarakat hingga mandiri pada satu sisi, sekaligus dapat mendidik para santrinya untuk terjun secara langsung di tengah masyarakat sebagai pembelajaran.

\section{E. Proses Pendidikan Pesantren}

Dalam proses pendidikan pesantren menurut KH. Abdurrahman Wahid model pembelajarannya bukanlah sekedar menguasai ilmu-ilmu keagamaan, melainkan juga proses pembentukan pandangan hidup dan prilaku para santri yang nantinya setelah keluar dari pendidikan pesantren mampu masuk ke dalam kehidupan masyarakat. ${ }^{98}$ Sebaliknya para kiai adalah mereka yang telah memiliki kesempurnaan pandangan (wâshilun). Di dalam pengertian tasawuf, pesantren merupakan tempat pertempuran moral berlangsung diantara para sâlikun, yang akan dirubah prilakunya oleh wâshilun. ${ }^{99}$

Proses pengajarannya di lembaga pendidikan pesantren menurut KH. Abdurrahman Wahid lebih banyak bersifat doktriner, ${ }^{100}$ dan ciri tersebut tetap harus dipetahankan sampai kepada sistem sekolah dan madrasah. ${ }^{101}$ Proses pendidikan dilingkungan pesantren dengan menggunakan teknik proses belajar mengajar dengan menggunakan metode sorogan, wetonan, halaqah dan hafalan. Hal ini terlihat pada gambar di bawah ini.

\footnotetext{
${ }^{94}$ KH. Abdurrahman Wahid, Menggerakkan Tradisi Esai-Esai Pesantren, hlm. 205.

${ }^{95}$ Lukman Hakim, Perlawanan Islam Kultural, (Surabaya: Pustaka Eureka, 2004), hlm. 115.

${ }^{96} \mathrm{KH}$. Abdurrahman Wahid, Menggerakkan Tradisi Esai-Esai Pesantren, hlm. 155.

${ }^{97}$ KH. Abdurrahman Wahid, Menggerakkan Tradisi Esai-Esai Pesantren, hlm. 156.

${ }^{98}$ KH. Abdurrahman Wahid, Menjawab Kegelisahan Rakyat, (Jakarta: Kompas, 2010), hlm. 134.

${ }^{99} \mathrm{KH}$. Abdurrahman Wahid, Menjawab Kegelisahan Rakyat, hlm. 135.

${ }^{100} \mathrm{KH}$. Abdurrahman Wahid, Bunga Rampai Pesantren, hlm. 28-9.

${ }^{101}$ Karena memiliki kelebihan yakni: pertama, kemampuan menciptakan sebuah sikap hidup universal yang merata, yang diikuti oleh semua warga pesantren sendiri, dilandasi dengan tata nilai di atas. Kedua, kemampuan memelihara subkultur sendiri. KH. Abdurrahman Wahid, Menggerakkan Tradisi Esai-Esai
} Pesantren, hlm. 73. 
Gambar. 4.6.

Proses pendidikan di pesantren

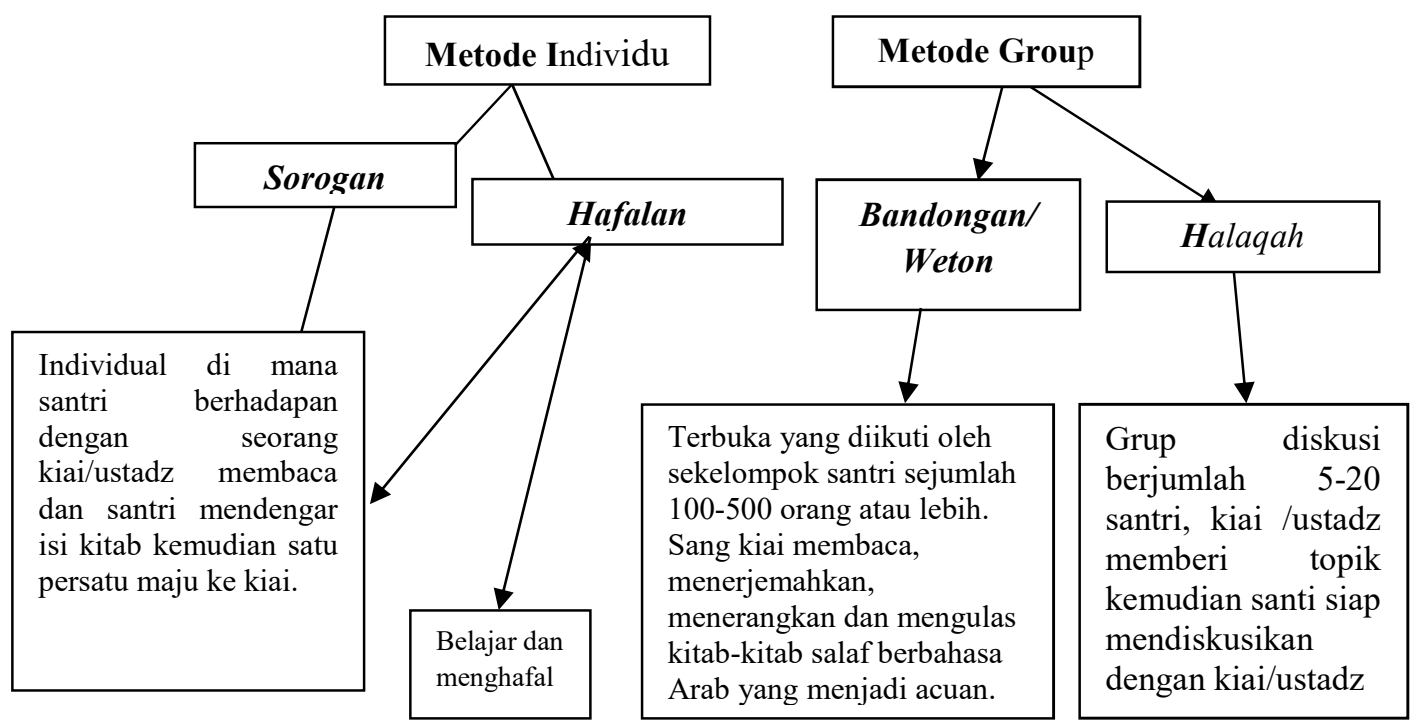

Keempat metode di atas, baik yang model individu maupun sistem group merupakan kekhususan dari proses pembelajaran pada pendidikan pesantren. Keempat metode ini, juga mengindikasikan peranan kiai sangat dominan dalam kegiatan pembelajaran. Karena itu, menurut Endin Mujahidin proses pembelajaran ini mengarah pada orientasi yang mendorong santrinya untuk menguasai materi secara utuh, sehingga pesantren menghasilkan lulusan yang sangat kuat penguasaan materinya tetapi sangat lemah dalam metodologi berfikirnya. ${ }^{102} \mathrm{Hal}$ ini disebabkan, karena teknik proses pendidikan pesantren di atas, dapat dikatakan sebagai pendidikan tuntas adalah model pembentukan kepribadiannya. Karena proses pendidikan pesantren, santri tidak didik pada aspek kognitif saja, melainkan yang lebih fundamental adalah aspek afektif dan psikomotoriknya. Latihan-latihan spiritual dan hormat kepada kiai, ustadz, sangat ditekankan, juga didorong untuk mencontoh perilaku kiai sebagai tokoh panutan, serta santri dilatih untuk mandiri baik dalam belajar maupun dalam pemenuhan kebutuhan sehari-harinya. Kesemuan ini dilakukan melalui pola relasi kiai dengan santri, dalam waktu 24 jam kiai dan ustadz memantau dan mengarahkan seluruh aktivitas santri agar mempunyai pengetahuan keagamaan dan prilakunya yang dikembangkan di pendidikan pesantren. ${ }^{103}$ Dengan demikian proses pembentukan kepribadian santri dilakukan secara sistematis dengan pola komunikasi kiai, ustadz dan santrinya dengan baik.

Ketaatan yang tinggi ini, menurut KH. Abdurrahman Wahid muncul rasa segan terhadap kiai, oleh karena tingginya otoritas dan wibawa kiai, sehingga melawan kiai dapat menghilangkan keberkahan ustadz dan santri. ${ }^{104}$ Demikian besar kekuasaan kiai atas diri santrinya, sehingga santri untuk seumur hidupnya senantiasa terikat dengan kiainya, minimal

${ }^{102}$ Endin Mujahidin, Pesantren Kilat Alternatif Pendidikan Agama di Luar Sekolah, (Jakarta: Pustaka Al-Kautsar, 2005), hlm. 48.

${ }^{103}$ Husni Rahim, Arah Baru Pendidikan Islam di Indonesia, hlm. 152.

${ }^{104} \mathrm{KH}$. Abdurrahman Wahid, Pesantren Masa Depan, hlm. 14. 
sebagai sumber inspirasi dan sebagai penunjang moral dalam kehidupan pribadinya. ${ }^{105} \mathrm{Hal}$ ini diungkap oleh Dardiri bahwa hubungan ustadz dan santri adalah sangat akrab, bebas dan demokratis, kecuali hubungan santri dan kiainya serta keluarganya masih terdapat sifat-sifat otoriter dan kiai dipandang sebagai orang harus dipatuhi ${ }^{106}$ Pola hubungan ini dapat menciptakan fanatisme bagi santri, misalnya santri berani mati karena membela kiainya.

Model komunikasi seperti di atas, menurut KH. Abdurrahman Wahid sebagai bentuk keunikan proses pendidikan pesantren sehingga mempunyai kelebihan dalam proses pendidikan pesantren. Kelebihan itu dapat lihat sebagai berikut: Pertama, kemampuan menciptakan sebuah sikap hidup universal yang merata, yang diikuti oleh semua warga persantren sendiri, yang dilandasi oleh tata nilai seperti yang disebut di atas. Kedua, kemampuan memelihara subkulturnya sendiri. ${ }^{107}$ Namun demikian, menurut KH. Abdurrahman Wahid proses pendidikan pesantren juga mempunyai kelemahan, antara lain, tata nilai yang terlalu menekankan pekerjaan praktik, yang cenderung menghasilkan santri yang hanya tunduk, taat tanpa memperhatikan keduniawian. Hal ini menyebabkan santri bersifat menerima begitu saja apa yang diajarkan oleh kiai, bahkan kerja ritual lebih utama daripada penyuluhan administratif. ${ }^{108}$ Jadi menurut KH. Abdurrahman Wahid perlu adanya kemauan pesantren untuk melakukan inovasi yang sesuai dengan perkembangan modern, walaupun masih terbatas pada soal-soal non-ritual dan non-konsepsional seperti pada dalam bidang administrasi dan lain-lain. ${ }^{109}$

Untuk menutupi kelemahan proses pendidikan pesantren, maka KH. Abdurrahman Wahid menjelaskan pada tiga hal yaitu: Pertama, sepanjang menyangkut tata nilai dan pandangan hidup yang ditimbulkannya di pesantren, harus tetap dikembangkan karena memiliki cukup banyak kelebihan. Kedua, sebaiknya ada usaha-usaha untuk menyempurnakan sistem pengajaran yang ada di pesantren harus diteruskan, terutama mengenai metode pengajaran dan penetapan materi pelajaranya sekaligus. Ketiga, Untuk memberikan landasan yang kokoh kepada usaha menyempurnakan sistem pengajaran yang ada, harus dirumuskan sebuah filsafat agama yang tradisional jelas dan terperinci. Dari filsafat pendidikan yang demikian itu, disusun kurikulum dan silabus sebuah sistem pendidikan agama tradisional dengan literatur baru guna dikembangkan selanjutnya. ${ }^{110}$ Pemikiran KH. Abdurrahman tersebut, dapat dipahami bahwa proses pendidikan pesantren dalam menuju ke arah yang positif dan berjalan dengan baik, harus memasukkan paradigma filsafat ${ }^{111}$ sebagai landasan dalam dunia pendidikan pesantren. Secara umum dalam pembahasan metode di atas, pada dasarnya masih efektif dan efisien untuk diterapkan, dengan catatan: (1) Metode sorogan harus dimbangi dengan jumlah pendidik yang cukup, jangan sampai kiai menghadapi ratusan bahkan ribuan santri dalam proses belajar. (2) Dalam metode badongan atau weton harus dibatasi jumlah santri yang belajar dalam satu kelompok (klasikal), dan adanya kejelasan makna pembelajaran, kitab yang dipakai, proses evaluasi,

${ }^{105}$ KH. Abdurrahman Wahid, Islam Kosmopolitan, hlm. 94.

${ }^{106}$ Karel A. Steenbrink, Pesantren Madrasah Sekolah, hlm. 76.

${ }^{107}$ KH. Abdurrahman Wahid, Menggerakkan Tradisi Esai-Esai Pesantren, hlm. 73.

${ }^{108}$ KH. Abdurrahman Wahid, Menggerakkan Tradisi Esai-Esai Pesantren, hlm. 22.

${ }^{109}$ KH. Abdurrahman Wahid, Menggerakkan Tradisi Esai-Esai Pesantren, hlm. 22.

${ }^{110}$ KH. Abdurrahman Wahid, Menggerakkan Tradisi Esai-esai Pesantren, hlm. 77.

${ }^{111}$ Menurut Ahmad Tafsir dalam Islam ada tiga paradigma pengetahuan yakni: Pertama, pengatahuan sains yaitu pengetahuan yang diperoleh dengan akal dan indera. Paradigma ini adalah logis dan empiris. Kedua, pengetahuan filsafat, paradigmanya rasional dan tidak empiris. Ketiga, pengetahuan mistik (supra rasional) yaitu suatu cara memperoleh pengetahuan tentang obyek-obyek abstrak. Hal ini dapat dilihat matrik berikut ini: Ahmad Tafsir, Filsafat Ilmu, hlm. 5-11. 
dan syarat-syarat santri naik ke tingkat selanjutnya. (3) Metode halaqah lebih efektif dan efisien, apabila dilaksanakan secara terjadwal, kiai yang menjadi pembimbing dan rancangan materi pelajaran di diskusikan. (4) Metode pelajaran semakin efektif dan efisien bila ditentukan pelajaran yang harus dihafal dengan batasan tertentu, metode hafalan harus diimbangi dengan pemahaman santri terhadapa pelajaran yang dihafal, agar terhindar dari istilah membeo, maksudnya dapat mengucapkan dengan benar dan tepat, namun tidak mengerti dengan kegunaan maksud dan tujuan pelajarannya. ${ }^{112}$

Analisis di atas, memberikan keterangan bahwa proses pendidikan pesantren tetap menjadi lembaga pendidikan masa depan jika point-point di atas diterapkan. Karena pesantren masa depan adalah pesantren yang senantiasa melakukan terobosan dan mereproduksi ilmu dalam berbagai bidang yang sesuai dengan kondisi sekarang dan yang akan datang, serta tetap pada tradisinya, inilah yang dimaksudkan KH. Abdurrahman Wahid dinamisasi pesantren. Dengan kata lain, sistem nilai yang ada dalam proses pendidikan pesantren tetap dipertahankan, namun berkaitan proses pengajaran di pesantren harus mengalami perubahan sesuai dengan perkembangan zaman tanpa meninggalkan yang tradisi yang lama secara rasional, sehingga ide-ide pondok pesantren dapat melakukan uji coba agar menunjukkan perubahan yang membawah eksistensi proses pendidikan pesantren itu sendiri.

\section{F. Evaluasi Pendidikan Pesantren}

Dalam pendidikan pesantren evaluasi menjadi hal yang penting, namun evaluasi dalam sistem pendidikan pesantren sering dilakukan dalam bentuk lisan atau tidak tertulis dimana santri dinilai langsung oleh kiai, dan ditentukan oleh penampilan serta kemampuan mengajarkan kitab kepada orang lain. ${ }^{113}$ Jika audiensnya merasa puas, maka hal itu berarti santri yang bersangkutan telah lulus, sebagai legalisasi kelulusan adalah restu kiai bahwa santri yang bersangkutan boleh pindah mempelajari kitab lain yang lebih tinggi tingkatanya, dan boleh mengajarkan kitab yang telah dikuasai kepada orang lain.

Evaluasi mempunyai fungsi dan peranan dalam aktivitas pendidikan, sebagai berikut:

1. Untuk menjadi dasar pembahasan keputusan dan pengambilan kebijakan dalam suatu lembaga pendidikan.

2. Untuk mengukur prestasi dan kemampuan peserta didik.

3. Untuk mengevaluasi kurikulum dan memantau pemanfaatan fasilitas dalam belajar mengajar.

4. Untuk memperbaiki materi program pendidikan

5. Untuk mengukur keberhasilan pendidik pendidik dalam penguasaan bahan, metode, dan sebagainya. ${ }^{114}$

Peran evaluasi pendidikan di atas, memberikan konsep bahwa evaluasi merupakan hal yang penting dalam mengukur kemajuan pendidikan. Karena itu, sistem pendidikan pesantren harus berupaya mengembangkan evaluasi pendidikannya. Secara rinci, upaya pengembangan evaluasi pendidikan pesantren sebagai berikut: Pertama, menyusun pedoman evaluasi pendidikan pondok pesantren yang terdiri atas keberhasilan akademik, watak dan pribadi, keimanan dan ketaqwaan baik melalui tes lisan dan tulisan. Kedua, evaluasi yang disusun dijadikan pedoman evaluasi pendidikan pesantren yang lebih

\footnotetext{
${ }^{112}$ Dawam Raharjo (ed), Pesantren dan Pembaharuan, hlm. 88-93.

${ }^{113}$ Mastuhu, Dinamika Sistem Pendidikan Pesantren, hlm. 145.

${ }^{114}$ Tedi Priatna, Cakrawala Pendidikan Islam, hlm. 229.
} 
mementingkan keberhasilan belajar fungsional daripada evaluasi yang bersifat pengertian dan formal, serta lebih memperhatikan keseluruhan perkembangan santri. Ketiga, evaluasi dijadikan pedoman untuk memiliki prinsip-prinsip, seperti kesinambungan dan bersifat menyeluruh.

Keempat, evaluasi sebagai pedoman keberhasilan pendidikan pesantren dengan memiliki berbagai macam model evaluasi yang disesuaikan dengan tingkat kematangan, jenjang pendidikan, kepribadian. Kelima, hasil evaluasi harus didokumentasikan dan disesuaikan dengan tradisi yang ada dan berlaku, sesuai dengan obyektivitas dan kejujuran penilaian yang diberikan pimpinan pesantren atau kiai yang bersangkutan. Dengan kata lain, sistem evaluasi yang komprehensif, baik yang menyangkut domain kognitif, afektif, maupun psikomotorik.

Sistem pendidikan pesantren yang digagas KH. Abdurrahman Wahid tidak mencakup seluruh empat aspek yang disebutkan di atas. Tetapi KH. Abdurrahman Wahid menawarkan suatu alternatif pengembangan kurikulum di pesantren, yaitu pemberian program bimbingan, keterampilan, pengembangan masyarakat oleh pesantren, sebagai programprogram yang memberikan dampak positif bagi institusi pesantren dan jika programprogram tersebut terlaksana, maka pesantren akan mengalami kemajuan.

Selanjutnya jika gagasan KH. Abdurrahman Wahid tersebut, dianalisis dengan memakai teori sosial struktural fungsional Talcot Person yang mengemukakan bahwa agar sistem organisasi sosial dapat bertahan (survive) maka sistem harus memiliki empat hal yaitu $^{115}$ :

1. Adaptation (adaptasi), sistem harus menyesuaikan diri dengan lingkungan dan menyesuaikan lingkungan dengan kebutuhan.

2. Goal attainment (mempunyai tujuan), sebuah sistem harus mendefinisikan dan mencapai tujuan utamanya.

3. Integration (integrasi), sebuah sistem harus mengatur antar hubungan bagian-bagian yang menjadi komponennya.

4. Latency (pemeliharaan pola), sebuah sistem harus memperlengkapi, memelihara dan memperbaiki, pola-pola kultural yang menciptakan dan menopang motivasi.

Keempat fungsi tersebut menurut Parson berlangsung ke dalam empat sistem tindakan yaitu: Organisnisasi perilaku yang melaksanakan adaptasi, sistem kepribadian, yang melaksanakan pencapaian tujuan, sistem sosial yang menanggulangi fungsi integrasi, dan sistem kultural, yang melaksanakan fungsi pemeliharaan pola. Kelemahan teori yang dibangun Talcot Person tidak membicarakan tentang kepemimpinan sebuah organisasi, padahal kepemimpinan menjadi kunci melaksanakan program-program di atas, dalam struktur organisasi.

Teori struktur fungsional di atas, masih relevan untuk dipergunakan dalam melihat gagasan KH. Abdurrahman Wahid tentang sistem pendidikan pesantren yang mempunyai kesesuaian konsep tentang ketahanan suatu organisasi. Karena itu, konsep sistem pendidikan pesantren KH. Abdurrahman Wahid dapat dianalisis dengan teori di atas, maka dapat diduga bahwa sistem pendidikan pesantren dalam pemikiran KH. Abdurrahman Wahid dapat bertahan jika memiliki empat sistem fungsi di atas, hanya saja KH. Abdurrahman Wahid, menambahkan satu yaitu kepemimpinan yang kharismatik-birokratik-kolektif.

${ }^{115}$ George Ritzer dan Goodman J. Doglas, Teori Sosiologis Modern, terj. Alimadan, (Jakarta: Prenada, 2004), hlm. 121. 
Dengan demikian dapat dipahami, bahwa seluruh perubahan dan pengembangan sistem pendidikan pesantren harusnya dimulai dari kepemimpinan kiai, bahkan sistem pendidikan pesantren dalam pemikiran KH. Abdurrahman Wahid, mempunyai daya ketahanan kuat jika mampu melakukan lima fungsi sistem ini. Hal ini dapat digambarkan sebagai berikut:

Gambar 4.9.

Struktur Sistem Pendidikan Pesantren KH. Abdurrahman Wahid

\begin{tabular}{|l|l|}
\hline Organisasi perilaku (adaptasi) & Sistem kepribadian (goal attainment) \\
\hline Sistem Sosial (integration) & Sistem Kultural (latency) \\
\hline Kepemimpinan & birokratif-kolektif-kharismatik \\
\hline
\end{tabular}

Dari gambaran di atas, dapat pahami bahwa sistem pendidikan pesantren akan bertahan dalam menghadapi perubahan, sepanjang melakukan lima fungsi di atas.

\section{G. Kritik Pemikiran KH. Abdurrahman Wahid; Sistem Pendidikan Pesantren.}

Pertama, pemikiran KH. Abdurrahman Wahid tentang sistem pendidikan pesantren tulis pada tahun 1970-1980 pada saat masih muda atau istilah Greg Barton teoritis belum banyak dipengaruhi pemikiran liberalnya sedangkan pemikirannya tentang pribumisasi, humanisasi adalah gagasan yang ditulis di tahun 1980 dimana beliau bergumul pada hal-hal yang praktis dan liberal. Dua tarikan ini membuat KH. Abdurrahman Wahid tidak konsisten dengan pemikirannya. Hal terlihat ketika terpilih menjadi presiden RI, di satu pihak ia cenderung pada mistifikasi politik dan di lain pihak ia adalah pejuang demokrasi, pluralisme, sehingga terjadi kontradiksi, dan keduanya gagal di atasi menyebabkan ia harus langser dari tahta kepresidenan. Bagi Dhofier langsernya KH. Abdurrahman Wahid dari kursi kepresidenan berlangsung relatif muda, hal ini disebabkan melemahnya kekuatan aroma politik atau restu para kiai melemah. ${ }^{116}$

Dari pendapat di atas, memunculkan beberapa analisis ketika KH. Abdurrahman Wahid langser dari kepresidenan yakni: Pertama, KH. Abdurrahman Wahid dalam banyak hal sering memaksakan kehendak dalam mengambil keputusan politik secara monolitik. Kedua, KH. Abdurrahman Wahid terlalu percaya diri dan suka mengabaikan saran-saran kiai. Ketiga, terjadi erosi ketaatan kepemimpinan terhadap KH. Abdurrahman Wahid, setidaknya sejumlah warga NU berani berbeda sikap dengan KH. Abdurrahman Wahid dalam pandangan dan pilihan politik. Keempat, akibat keberhasilan pendidikan politik dan perjuangan demokrasi yang diajarkan oleh KH. Abdurrahman Wahid sendiri, ditandai semakin terbukanya wawasan kaum nahdliyin terhadap kehidupan berbangsa dan bernegara. Bahkan Saiful Mujani melihat ada perubahan komunikasi politik dari pusaran emotional choice ke rasional choice. ${ }^{117}$ Dengan demikian, dapat dipahami bahwa pergumulan politik

116 Wawancara Dhofier dengan beberapa kiai dan memberi nasehat agar KH. Abdurrahman Wahid memimpin dengan lebih bijak, dijawab KH. Abdurrahman Wahid bahwa ia lebih tau keinginan yang di atas. Selain itu, beberapa kiai yang bermaksud menemuinya di istana tidak berhasil. Zamakhasyari Dhofier, Tradisi Pesantren; Studi Pandangan Hidup Kyai dan Visinya, hlm. 262.

117 Saiful Mujani, Muslim Demokrat; Islam Budaya Demokrasi, dan Partisipasi Politik di Indonesia Pasca Orde Baru, (Jakarta: Gramedia Pustaka Utama, 2007), hlm. 253. 
KH. Abdurrahman Wahid, baik di organisasi NU maupun di pemerintahan mempunyai banyak variabel yang dimainkan. Salah satunya adalah seorang yang sangat percaya kepada kiai yang mampu memberikan jawaban atas peristiwa yang sedang dan bahkan akan terjadi, namun dalam pergumulan politiknya tidak lagi menggunakan kiai sebagai penasehat atau istilah yang dipakai konsultan politik, sehingga melemahnya restu kiai, bahkan cenderung kebijakan politik monolitik, sehingga resiko yang dibayar mahal oleh KH. Abdurrahman Wahid adalah langsernya dari panggung kekuasaan kepresidenan dan penulis menggunakan istilah kembalinya ke dunia pesantren yang dilupakan.

Kedua, sistem pendidikan pesantren KH. Abdurrahman Wahid tidak berhasil diimplementasikan dalam pesantren Ciganjur, hal terlihat pada beberapa hal ketika memotret jumlah santri dan pengaruhnya dengan memakai teori Dhofier dan Tafsir bahwa pesantren yang besar pengaruhnya adalah pesantren yang memiliki santri 1000-3000 dan yang santrinya kurang dari 1000 pengaruhnya hanya pada tingkat kabupaten. Dari segi pengaruh walaupun jumlah santri sedikit juga tidak mempunyai pengaruh yang signifikan.

Ketiga, pemikiran KH. Abdurrahman Wahid tentang demokrasi, pluralisme, pribumisasi, humanisme, sebenarnya tidak menemui fakta dalam tradisi pesantren, hal ini dibuktikan dalam penelitian Martin van Bruinessen yang mengatakan bahwa kitab-kitab yang dipakai di pesantren, baik bidang akidah, tasawuf, ushul fiqh, agak sulit untuk menarik adanya korespondensi tentang dokrin pluralisme, pribumisasi dan humanisme. Selain mayoritas kitab klasik tidak banyak bicara politik, juga orientasi pendidikan pesantren lebih diarahkan kepada transmisi pengetahuan melalui kitab-kitab kuning dan menyiapkan para penerus Islam tradisional. Kalaupun ada dengan upaya mereka sendiri, lebih akibat corak paternalistik.

Pemikiran KH. Abdurrahaman Wahid tentang pluralisme, pribumisasi, demokrasi tidak mendapat porsi dalam tradisi pesantren. Martin van Bruinessen ketika mengomentari cakupan kitab kuning tentang perempuan, berkesimpulan bahwa banyak agenda sosial lain yang menuntut perhatian, seperti perlindungan hak pekerja perempuan, kesamaan upa lakilaki dan perempuan untuk pekerjaan yang sama, status sosial janda, partisipasi perempuan dalam pendidikan, ekonomi dan politik dan lainnya tidak disinggung sama sekali dan bahkan sampai sekarang belum bisa dibicarakan dalam diskursus kitab kuning. Di tambah lagi dengan figur kepemimpinan kiai yang kharismatik sebagai komponen penting di pesantren, sangat kontradiksi dengan demokrasi dan pluralisme. Karena itu pemikiran KH. Abdurrahman Wahid tentang demokrasi, pluralisme, pribumisasi hanyalah sebuah gagasan yang sulit diwujudkan dalam dunia pendidikan pesantren. ${ }^{118}$

Keempat, sistem pendidikan pesantren yang dikemukakan KH. Abdurrahman Wahid, tidak menjadikan evaluasi sebagai alat dan indikator untuk mencapai tujuan sistem pendidikan pesantren yang digagasnya. Padahal teori evaluasi dalam pendidikan Islami adalah pengambilan sejumlah keputusan yang berkaitan dengan pendidikan Islami guna melihat sejauh mana keberhasilan pendidikan yang selaras dengan nilai-nilai Islam sebagai tujuan dari pendidikan Islami itu sendiri.

Kelima, sistem pendidikan pesantren yang digagas KH. Abdurrahman Wahid hanya sebagai teori pengembangan pendidikan pesantren. Karena itu, ia gagal membuktikan keempirisan dari teorinya dan hal ini disebabkan, karena KH. Abdurrahman Wahid melihat institusi pesantren secara utuh tidak ada konflik internal dan eksternal. Padahal salah satu yang bisa membuat pesantren tidak maju adalah konflik internal dan eksternal itu sendiri

${ }^{118}$ Ahmad Suhaedy, Pergulatan Pesantren dan Demokratisasi, (Yogyakarta: LKiS, 2000), hlm. 209. 
ditubuh pesantren. Di samping itu, KH. Abdurrahman Wahid bukan seorang praktisi dalam sistem pendidikan pesantren yang terlibat langsung, hanya sebagai pemandu atau konseptor untuk mengembangkan sistem pendidikan pesantren dalam menghadapi perubahan di masa yang akan datang. Karena itu, gagasan-gagasannya terkesan dipaksakan masuk dalam pendidikan pesantrennya dan tidak berhasil.

Namun demikian, gagasan sistem pendidikan pesantren KH. Abdaurrahman Wahid di atas, masih relevan dalam pengembangan sistem pendidikan pesantren masa sekarang. Tawaran yang dikemukakannya tentang pesantren, seperti tujuan, integrasi, penyederhanaan kurikulum, proses pengajaran serta kelembagaan pesantren yang terdiri dari peningkatan sarana, pemahaman manajemen kepemimpinan, kemandirian pesantren, dan beberapa yang lainnya, tetap merupakan agenda pesantren hingga sekarang. Karena itu, pemikiran pendidikan pesantren KH. Abdurrahman Wahid lebih pada teoritis bagaimana mengevaluasi dan mengembangkan pesantren lebih lanjut, baik secara individu maupun secara kolektif.

\section{H. Kesimpulan}

Berdasarkan rumusan masalah penelitian yang telah dikemukakan, maka penelitian ini menyimpulkan bahwa pemikiran KH. Abdurrahman Wahid tentang sistem pendidikan pesantren sebagai berikut:

1. Sistem pendidikan pesantren bersifat integral dalam merespon perubahan dengan tetap merujuk pada subkultur pesantren. Kesimpulan ini didasarkan pada beberapa aspek pemikiran KH. Abdurrahman Wahid yaitu: Pertama, aspek tujuan pendidikan pesantren bersifat dinamis tidak hanya pada upaya tafaqquh fi al-din, tetapi juga diperluas dengan penguasaan ilmu pengetahuan dan teknologi, sehingga santri memiliki wawasan yang luas, menguasai ilmu agama dan ilmu pengetahuan umum serta keterampilan. Dengan demikian, tujuan bergerak ke arah integrasi tujuan yaitu keseimbangan antara keimanan, ketaqwaan (Imtaq) dan penguasaan ilmu pengetahuan (Iptek). Tujuan ini harus dirumuskan secara tertulis. Kedua, aspek program pendidikan bersifat adaptif dengan tetap mempertahankan kitab-kitab klasik untuk mempertahankan reproduksi ulama, dan menggunakan integrasi kurikulum antara ilmu-ilmu agama dan umum, dengan menyederhanakan kurikulum pesantren, yang disesuaikan dengan perkembangan pengetahuan dan teknologi. Ketiga, aspek proses pendidikan pesantren, bersifat inovatif dengan tetap menerapkan metode pembelajaran sorogan dan wetonan yang menjadi ciri khas pendidikan pesantren, namun sebaiknya ada usaha-usaha untuk menyempurnakan sistem pengajaran yang ada di pesantren harus diteruskan, dan mengenai materi pelajaran sepanjang menyangkut tata nilai dan pandangan hidup yang ditimbulkannya di pesantren, harus tetap dikembangkan karena memiliki cukup banyak kelebihan.

2. Pada konsep institusi pesantren ada beberapa aspek yang dilaksanakan dalam menghadapi tantangan modernisasi sebagai berikut: pertama, pesantren tetap berpegang pada tradisi nilai-nilai dianutnya sehingga dapat berperan sebagai lembaga yang mampu memberikan sumbangan yang berarti dalam membangun sistem nilai dan kerangka moral pada individu dan masyarakat. Seperti sifat kesederhanaan, qanaah, keikhlasan serta etos kerja. Kedua, pesantren harus mampu menciptakan proses pendidikan yang berbasis pada masyarakat dan menjadi pusat pengembangan masyarakat, dengan melibatkan masyarakat dalam kegiatan pendidikan, hal ini sangat diharapkan dan sejalan dengan era reformasi dan otonomisasi. Ketiga, mengintegrasikan pesantren sebagai sistem pendidikan ke dalam pola umum pendidikan nasional, sehingga membentuk manusia 
cerdas kreatif. Keempat, pola kepemimpinan di dalam pendidikan pesantren harus memadukan kepemimpinan kharismatik dan kepemimpinan birokratik-kolektif.

\section{Daftar Pustaka}

, Jaringan Intelektual Kyai Pesantren di Jawa-Madura Abad XX, dalam Laporan Hasil Penelitian Kompetitif, Jakarta, Depertemen Agama RI, 2000. , (ed), Inovasi Pengelolaah Pesantren Terpadu dalam Menghadapi Persaingan di

Era Globalisasi, Bogor, Program Pascasarjana UIKA Bogor, 2012. , Memberdayakan Sistem Pendidikan Islam, Jakarta, Logos Wacana Ilmu, 1999. , Sistem Pendidikan Yang Visioner, Jakarta, Lentera Hati, 2007. , Wacana Pengembangan Pendidikan Islam, Yogyakarta, Pustaka Pelajar, 2003. , Dasar-Dasar Ilmu Pendidikan, Jakarta, Raja Grafindo Persada, 1999. , Kapita Selekta Pendidikan Islam, Jakarta, Raja Grafindo Persada, 2012. , Majalah Pesantren, (Jakarta, P3M, No. 2./Vol. IV, 1987. „Adian, et. al, Filsafat Ilmu Perspektif Barat dan Islam, Jakarta, Gema Insani, 2013

, Pendidikan Islam Membentuk Manusia Berkarakter dan Beradab, Jakarta Cakrawala Publishing, 2012. , Islamku Islam Anda Islam Kita, Jakarta, The Wahid Institute, 2006. , Visi Pembaharuan Pendidikan Islam, Jakarta, LP3NI, 1998. dkk, Cakrawala Pemikrian Pendidikan Islam, Bandung, Mimbar Pustaka,

2004. , Sejarah Pondok Pesantren di Indonesia, Jakarta, Dhanna Bakti, 1980. (ed), dalam Pesantren dan Pembaruan, Jakarta, LP3ES, 1985. , Filsafat Ilmu, Bandung, Remaja Rosdakarya, 2010.

, Filsafat Pendidikan Islam; Pendekatan Historis, Teoritis dan Praktis, Jakarta, Ciputat Pres, 2002.

, Islam dan Kemajemukan Indonesia, Studi Kasus Pesantren dan Pendidikan Multikultural, Annual Conference on Islamic Studies (ACIC) ke-10, Bajarmasin, 2010.

, Kapita Selekta Pendidikan Islam; Isu-Isu Kontemporer tantang Pendidikan Islam, (Jakarta: Rajagrafindo Persada, 2012.

, Konsep Pendidikan Ibnu Zina, Disertasi, Jakarta, IAIN Syarif Hidayatullah

Jakarta, 1997. , Manajemen Pendidikan Islam, Bandung, Erlangga, 2007. , Manajemen Pendidikan Islam, Jakarta, Prenada Media, 2003. , Metodik Khusus Pendidikan Islam, Bandung, Remaja Rosdakarya, 1992. , Paradigma Pendidikan Islam, Jakarta, Raja Grafindo, 2001. , Pemikiran Para Tokoh-Tokoh Pendidikan Islam, Jakarta, Raja Grafindo Persada, 2000. Kapita Selekta Pendidikan Islam, Bandung, Angkasa, 2003. , Pengantar Dasar-Dasar Pemikiran Pendidikan Islam, Nizar, Jakarta: Gaya Media Pratama, 2001. 
2001.

, Peta Keragaman Pemikiran Islam di Indonesia, Jakarta, Raja Wali Press,

, Studi Islam Komprehensif, Jakarta, Prenada Media Group, cet. I 2011.

, Tafsir Al-Mishbah, Pesan, Kesan, dan Keserasian Al-Qur'an, Vol. 11, .

,'Mozaik Pesantren", Jurnal Modernisasi Manajemen Pendidikan

Pesantren, Direktorat Pendidikan Keagamaan dan Pondok Pesantren dan PT. Ababil

Citra Media, Edisi 02/Tahun I/Nopember 2005.

, Esai-Esai Intelektual Muslim dan Pendidikan Islam, Jakarta, Logos

Wacana Ilmu, 1998.

, Esai-Esai IntlektualMuslim dan Pendidikan Islam, Jakarta, Logos Wacana

Ilmu, 1998.

, Filsafat Pendidikan dalam al-Qur'an, terj. Jakarta, Pepara, 1986.

, Islam Kosmopolitan, , Jakarta, The Wahid Institute, 2007.

, Metodologi Studi Islam, Jakarta, RajaGrafindo Persada, 2001.

, Sejarah Sosial Intelektual Islam dan Institusi Pendidikannya, Jakarta, Raja

Wali Pers, 2012.

, Pesantren Studies 2a, Kosmopolitanisme Peradaban Kaum Santri di

Masa Kolonial, Juz Pertama, Pesanteren Jaringan Pengetahuan dan Karekater

Kosmopolitan-Kebangsaan, Jakarta, Pustaka Afid, 2012.

, "Neo-Modernisme Islam Versus Post-Tradisionalisme Islam", dalam

Jurnal Taswirul Afkar, edisi No. 9, Jakarta, Lakpesdam, 2000.

, Gagasan Islam Liberal Indonesia, Jakarta, Paramadina, 1999.

, Histiografi Islam Kontemporer; Wacana Aktualitas dan Aktor Sejarah,

Jakarta, Gramedia, 2002.

, Islam Reformis Dinamika Intelektual dan Gerakan, (Jakarta:

RajaGrafindo Persada, 1999.

, Jaringan Ulama Timur Tengah, Bandung, Mizan, 1994.

, Kitab Kuning, Pesantren dan Tarekati:Tradisi-Tradisi Islam di

Indonesia, Bandung, Mizan, 1999.

, Nilai-Nilai Pluralisme dalam Islam, Jakarta, Nuansa Fatayat NU dan

Ford Foundation, 2005.

2002

, Paradigma Baru Pendidikan Nasional, Rekonstruksi, Jakarta, Kompas,

, Pendidikan Antisipatoris, Yogyakarta, Kanisius, 2001.

,'Pesantren: Kontinuitas dan Perubahan," Pengantar buku Nurcholish

Madjid, Bilik-Bilik Pesantren, Jakarta, Yayasan Wakaf Paramadina, 1997.

, Tafsir Al-Mishbah Volume 10, Jakarta: Lentera Hati, 2008.

Tafsir Al-Mishbah, Pesan, Kesan dan Keserasian Al-Qur'an, Volume

„Tafsir Al-Mishbah, Pesan, Kesan, dan Keserasian Al-Qur'an, Vol. 13,

„Tafsir Al-Mishbah, Pesan, Kesan, dan Keserasian Al-Qur'an, Vol. 14.

, Tafsir al-Quranul Karim, Bandung, Pustaka Hidayah, 1997.

dkk, Religiutas IPTEK, Rekontruksi Pendidikan dan Tradisi Pesantren,

Yogyakarta, Pustaka Pelajar, 1998.

, Dari Haramain ke Nusantara Jejak Intelektual Arsitek Pesantren,

Jakarta, Prenada, 2006. 
Yogyakarta, Tiara Wacana, 2000.

Historitas dan eksistensi, Pesantren, Sekolah dan Madrasah, , Kiai Nyentrik Membela Pemerintah, Yogyakarta, LKiS, 1997. , Melawan Melalui Lelucon, Jakarta, Tempo 1980. , Membangun Demokrasi, Bandung, Remaja Rosdakarya, 1999. , Menggerakkan Tradisi Esai-Esai Pesantren, Yogyakarta, LKis, 2011. , Mengurai Hubungan Agama dan Negara, Jakarta, Grasindo, 1999. , Menjawab Kegelisahan Rakyat, Jakarta, Kompas, 2010. , Nalar Spritual Pendidikan Islam, Solusi Problem Filosofi Pendidikan Islam, Yogyakarta, Tiara Wacana, 2002.

, Paradigma Intelektual Muslim, Yogyakarta, Sipress, 1993.

, Pergulatan Negara, Agama, dan Kebudayaan, Jakarta, Desantara,

2001. , Pesantren Masa Depan, Bandung, Pustaka Hidayah, 1999. , The Concept of Education in Islam, A. Framework for An Philosophy of Education, Kuala Lumpur, Muslim Youth Movement of Malaysia, ABIM, 1980. , Tuhan Tak Perlu Dibela, Yogyakarta, LkiS, 1999 , Modernaisasi Pesantren; Studi Transformasi Kepemimpinan Kiai dan Sistem Pendidikan Pesantren, (Yogyakarta: LKiS, 2013. , Pemikiran dan Sikap Politik Gusdur, Jakarta, Erlangga, 2010.

Abd. Rahman Shaleh, et, al., Pedoman Pembinaan Pondok Pesantren, Jakarta, Proyek Pembinaan dan Bantuan kepada Pondok Pesantren Departemen Agama RI, 1985.

Abdul Madjid dan Andayani, Pendidikan Karakter dalam Perspektif Islam, Bandung, Remaja Rosdakarya, 2011.

Abdul Mukti, Ismail SM, ,(ed), Pendidikan Islam Demokratisasi dan Masyarakat Madani, Yogyakarta, Pustaka Pelajar, 2000.

Abdullah, Irwan, Pengantar Metode Penelitian Kualitatif, Yogyakarta, Sekolah Pascasarjana Universitas Gadjah Mada Media, 2007.

Abdullah, M. Amin, dkk., Metodologi Penelitian Agama; Pendekatan Multidisipliner, Yogyakarta: Lembaga Penelitian UIN Sunan Kalijaga, 2006.

Abdullah, Taufik (Ed), Agama dan Perubahan Sosial, Jakarta, Rajawali Press, 1983.

Abu Ahmadi dan Nur Uhbiyati, Ilmu Pendidikan, Jakarta: Rineka Cipta, 2001.

Abuddin Nata, Filsafat Pendidikan Islam, Jakarta, Logos Wacana Ilmu, 1997.

Ahmad Syahid dan Abas Al-Jauhari, (ed), Bahasa, Pendidikan, dan Agama, Jakarta, Logos Wacana Ilmu, 2002.

Ahmad, Munawar, Ijtihad Politik Gus Dur Analisis Wacana Kritis, Yogyakarta, LKiS, 2010. al-Abrasyi, Atiyah, al-Tarbîyah al-Islamîyah wa Falâsifatuha, cet. III, Mesir, Isa al-Baby al-halaby tt.

Al-Abrasyi, Moh. Athiya, Dasar-Dasar Pokok Pendidikan Islam, terj. Jakarta, Bulan Bintang, 1980.

al-Amir, Najib Khalid, Tarbiyah Rasulullah, Jakarta, Gema Insani Press, 1992.

al-Attas, Syed Muhammad Naquib, Konsep Pendidikan Islam, terj. Bandung, Mizan, cet III, 1990. ,Islam and Sekularisme, Bandung: Pustaka, 1981.

al-Djamali, Fadhil, Menerebas Krisis Pendidikan Dunia Islam, Jakarta, Golden Terayon Press, 1988.

Ali Jumbulati dan Abdul Futuh At- Tuwaanisi, Dirâsah Muqarânah fí al-Tarbîyat alIslâmîyah, terj. Jakarta, Rineka Cipta, Cet II 2002. 
Ali Khalîl, Abu al-'Ainain, ', Falsafah al-Tarbiyah al-Islâmiyah fi al-Qur'ân al-Karîm, Kairo, Dâr al-Fikr al-’ Arabiy, Cet. I, 1980.

Ali, A. Mukti, Beberapa Persoalan Agama Dewasa ini, Jakarta, Rajawali, 1987.

al-Maudûdî, Abû al-A'lâ, Manhaj al-Islâmîyah al-Jadîd li al-Tarbîyah wa al-Ta'lîm, Damsyik, al-Maktabah al-Islamî, 1985.

Al-Munawar, Said Agil Husin, Aktualisasi Nilai-Nilai Qur'ani dalam Pendidikan Islam, Jakarta, Ciputat Press, 2003.

al-Qardhawi, Yusuf, Pendidikan Islam dan Madrasah Hasan al-Banna, terj. Jakarta: Bulan Bintang, 1980.

Al-Syaibani, Omar Mohammad Al-Toumy, Fasalfah Pendidikan Islam, Terj. Hasan Langgulung, Jakarta, Bulan Bintang, 1984.

Al-Zarnujî, Ta'lìm al-Mutâllim Tarîq al-Ta'allum, (Beirut: Dâr Ihyâ' al-Kutub al-'Arabîyah, tt.

al-Zastrouw, Ng Cf.., Gus Dur Siapa Sih Sampeyan? Tafsir Teoritik atas Tindakan dan Pernyataan Gus Dur, Jakarta, Erlangga, 1999.

Amin, Haedari, Jurnal Pondok Pesantren Mihrab, vol. II No. 1 Juli 2007.

Amir Faisal, Jusuf, Reorentasi Pendidikan Islam, Jakarta, Gema Insani Press, 1995.

Amirin, Tatang, Pengantar Sistem, Jakarta, Rajawali Press, 1886.

Amirul Hadi dan Haryono, Metodologi Penelitian Pendidikan, Bandung, Pustaka Setia, 1998.

An Nahlawi, Abdurrahman, Pendidikan Islam di Rumah, Sekolah, dan Masyarakat, Jakarta, Gema Insani Press, 1995.

Azra, Azyumadi, Pendidikan Islam; Tradisi dan Modernisasi Menuju Milenium Baru, Jakarta, Logos Wacana Ilmu, 2000.

Badri Yatim dkk, Sejarah Perkembangan Madrasah, (Jakarta: Depag RI, 1999.

Bahar, Ahmad, Biografi Kiai Politik Abdurrahman Wahid; Gagasan dan Pemikiran, Jakarta, Bina Utama, 1999.

Bahar, Herwina, Dalam Jurnal Pemikiran Islam Kontemporer, Miskatul Anwar, Tujuan Pendidikan Dalam Persfektif Al-Qabisi, Volume 7, 1 Juni 2001.

Barton, Greg, Biografi Gusdur, Yogyakarta, LKiS, 2002.

Baso, Ahamd,'Kembali Ke Pesantren, Kembali Ke Karakter Ideologi Bangsa", dalam Jurnal Karsa, Vol. 20 No. 1 Tahun 2012.

Bawani, Imam, Tradisionalisme dalam Pendidikan Islam, Surabaya: al-Ikhlas, 1993.

Benda, Harry J., Bulan Sabit dan Matahari Terbit, Islam di Indonesia Pada Masa Pendudukan Jepang, Terj, Jakarta, Pustaka Jaya, 1985.

Bloom, Bejamin S. (ed), Taxnomy of Education Obfectives Handbook 1, Cognitive Domain, New York: Longman Inc, 1956.

Bourdieu, Pierre, Outline of A Theory of Practice, Cambridge, University Press, 1977.

Bruinenssen, Martin Van, NU; Tradisi Relasi-relasi Kuasa, Pencarian Wacana Baru, Yogyakarta, LKiS, 1994.

Buchori, Muchtar, Ilmu Pendidikan dan Praktek Pendidikan, Jakarta, Muhammadiyah Press, 1994.

Bukhori,Umar,"Status Pesantren Mu'adalah antara Pembebasan dan Pengebirian Jatidiri Pendidikan Pesantren", dalam Jurnal Karsa, Vol. ixi No. 1 April 2011.

Darban, "Kiai dan Politik pada Zaman Kerajaan Islam", dalam majalah Pesantren, No.2/Vol V, 1998. 
Darmawan, KH. Abdurrahman Wahid; Kiai Nyentrik Jadi Presiden, Yogyakarta, Lembaga Analisis Informasi, 1999.

Darwis (ed), Gus Dur, NU, dan Masyakat Sipil, Yogyakarta, LKiS, Cet I, 1994.

Daulay, Haidar Putra, Sejarah Pertumbuhan dan Pembaruan Pendidikan Islam di Indonesia, Jakarta, Prenada, 2007.

Dedy Djamaluddin Malik dan Idi Subandy Ibrahim, Zaman Baru Islam Indoensia Pemikiran dan Aksi Politik, Bandung, Zaman Wacana Mulia, cet. I, 1998.

Depertemen Agama RI, Ilmu untuk Disiplin Pendidikan, Buku Daras Pendidikan Islam Pada Perguruan tinggi Umum, Jakarta, Depag, 2000.

Dhakiri, M. Hanif, 41 Warisan Kebesaran Gus Dur, Yogyakarta, LKiS, 2010.

Dhofier, Zamakhasyari, Tradisi Pesantren: Studi Tentang Pandangan Hidup Kiyai, Jakarta, LP3ES, 2011.

Didin, Hafidhuddin, Konsep Pendidikan Karakter Berbasis Pendidikan Agama, dalam jurnal Pendidikan Islam, Ta'dibuna, Vol 1/No. 1/ Juni 2011.

Dirdjosanjoto, Pradjarta, Memelihara Umat; Kiai Pesantren-Kiai Langgar di Jawa, Yogyakarta, LKiS, 1999.

Djamas, Nurhayati, Dinamika Pendidikan Islam di Indonesia Pasca Kemerdekaan, (Jakarta: RajaGrafindo Persada, 2009.

Djauhari, Muhammad Tidjani, Masa Depan Pesantren; Agenda yang Belum Terselesaikan, Jakarta, Taj Publishing, 2008.

Djohan Efendy menyampaikan hal ini di Simposium, Kristalisasi Pemikiran Gus Dur, Jakarta, 16-18 Nopember 2011.

Djuwaeli, H.M. Irsyad, Pembaharuan Kembali Pendidikan Islam, Jakarta: Yayasan Karsa Utama Mandiri, Cet I, 1998.

Edwin A. Locke, Esensi Kepemimpinan; Empat Kunci untuk Memimpin dengan Penuh Keberhasilan, Jakarta, Mitra Utama, 1997.

Effendy, Bahtiar, Teologi Baru Politik Islam, Pertautan Agama, Negara, dan Demokrasi, Yogyakarta, Galang Press, 2001.

Fadjar,A. Malik, Reorientasi Pendidikan Islam, Jakarta, Fajar Dunia, 1999.

Faisal, Sanapiah, Metodologi Penelitian Pendidikan, Surabaya, Usaha Nasional, 1982.

Faisal, Yusuf Amir, Reorientasi Pendidikan Islam, Jakarta, Gema Insani Press, Cet I, 1995.

Faridl Miftah,'Peran Sosial Kiai di Indoensia", dalam Jurnal Sosaoteknologi Edisi 11, 6 Agustus, 2007.

Faturahaman, Pupuh, Keunggulan Pendidikan Pesantren; Alternatif Sistem Pendidikan Terpadu Abad XXI, Bandung, Tunas Nusantara, 2000.

Firdaus, Komunikasi Politik Elit NU Pasca Orde Baru, Disertasi UIN Jakarta, tidak terbit, 2008.

Firhat, Ahmad Hasan, Khalîfah fî al-Ard; Pembahasan Kotekstual, Jakarta, Cakrawala Persada, 1992.

Frans M. Parera dan T. Jakob Koekerits, Gus Dur Menjawab Perubahan Zaman, Jakarta, Kompas, 1999.

Freire, Paulo, Politik Pendidikan, Kebudayaan, Kekuasaan, dan Pembebasan, terj. Yogyakarta, Pustaka Pelajar, 2000.

Fuad Anwar, Melawan Gusdur, Yogyakarta, LKiS, 2004.

Fuad Jabali dan Jamhari (penyunting), IAIN Modernisasi Islam di Indonesia, Jakarta, Logos Wacana Ilmu, 2002. 
Gaus, Ahmad, “Hanya Insan Biasa; Membuka Wacana Umat dan Ruang Publik”, dalam Pesantren, No. 69, Tahun II, 05, 2000.

Giddens, Anthony, Kapitalisme dan Teori Sosial Modern: Suatu Analisis Karya-Karya Tulis Marx, Durkheim dan Max Weber, terj. Oleh Soeheba Kramadibrata, Jakarta, UIP, 1985.

Hafidhuddin, Didin, "Konsep Pendidikan Karakter Berbasis Agama”, dalam Jurnal Pendidikan Islam, Ta'dibuna, Vol 1/No. 1/ Juni 2011.

Hakim, Lukman, Perlawanan Islam Kultural, Surabaya, Pustaka Eureka, 2004.

Hakim, Sudarnoto Abdul dkk. (Ed), Islam Berbagai Perspektif: Didedikasikan untuk 70 Tahun Prof. Dr H. Munawir Sjadzali, MA., Yogyakarta, LPMI, 1995.

Halim, A, (ed), Manajemen Pendidikan Pesantren, yogyakarta, LkiS, 2005.

Hans Wehr, dan J. Milton Cowan(ed), A. Dictionary of Modern Written Arabic Beirut, Librarie, and London, Macdonald \& Evans LTD, 1974.

Hasbi, Indra, Pesantren dan Transformasi Sosial; Studi Atas Pemikiran K.H. Abdullah Syafi 'i dalam Bidang Pendidikan Islam, Jakarta, Penamadani, 2003.

Hasbullah, Sejarah Pendidikan Islam di Indonesia, Jakarta, Raja Grafindo Persada, 1999.

Hasingsih, Sri, "Peran Strategis Pesantren, Madrasah, dan Sekolah Islam di Indonesia", ElTarbawi Jurnal Pendidikan Islam, No. 1. Vol. 1. 2008.

Hassan Muhammad Hassan dan Nadiyah Jamaluddin, Madaris al-Tarbiyah fi al-Hadarah al-Islamiyah, Kairo, Dar al-Fikr al-'Arabi, 1984.

Hery Noer Aly, H. Munzier S., Watak Pendidikan Islam, Jakarta, Friska Agung Insani, 2000. Hidayat, Komaruddin, Wahyu di Langit Wahyu di Bumi; Doktrin dan Peradaban Islam di Panggung Sejarah, Jakarta, Paramadina, 2003.

Hidayat, Komaruddin,'Kiai dan Dunia Pesantren", dalam Marwan Saridjo (penyunting), Mereka Bicara Pendidikan Islam Sebuah Bunga Rampai, Jakarta, Raja Grafindo Persada, 2009.

Horikoshi, Hiroko, Kiyai dan Perubahan Sosial, Terjemahan, Umar Baslim dan Andy Muarly Sunrawa, Jakarta, P3M, 1987.

Howard R. Turner, Sains Islam Yang Mengagumkan, Terj. Zulfahmi Andri, Jakarta, Yayasan Nuansa Cendekia, Cet. I, 2004.

Husaini, Adian, " Makna Adab Dalam Perspektif Pendidikan Islam”, dalam Jurnal Pendidikan Islam, Ta'dibuna, Program Doktor Pendidikan Islam Universitas Ibn Khaldun Bogor,:Vol 1/No. 1/ Juni 2011.

Husein, Machnun, Pendidikan Islam dalam Lintasan Sejarah, Yogyakarta, Nur Cahaya, 1983.

Ibrahim, Hasan, Min 'Alami Tarbîyah Arabîyah Islâmiyah, Maktab, Tarbiyah al-Arabi Lidduali khalic, 1988.

Idi, Abdullah, Pengembangan Kurikulum Teori dan Praktik, Yogyakarta, Ar-Ruzz, 2007.

Iskandar, Muhaimin, Gus Dur Yang Saya Kenal, Yogyakarta, LKiS, 2004.

Ismail (ed), Paradigma Pendidikan Islam, Yogyakarta, Pustaka Pelajar, 2001.

Ismail al-Faruqi dan Lois Lamnya' al-Faruqi, The Cultural Atlas of Islam, New York, Macmillan Publishing Company, 1986.

Ismail dkk (ed), Paradigma Pendidikan Islam, Yogyakarta, Pustaka Pelajar, 2001.

Jalal, Abdul Fattah, Azaz-Azaz Pendidikan Islam, Terj. Harry Noer Ali, Bandung CV. Diponegoro, 1988.

Jalal, Fasli, Reformasi Pendidikan dalam Konteks Otonomi Daerah, Yogyakarta, Adicita, 2001. 
Jalaluddin, Teologi Pendidikan Islam, Jakarta, Rajagrafindo Persada, 2001.

John M. Echol dan Hasan shadily, Kamus Inggris Indonesia, Jakarta, Gramedia, 1980.

John. O Vall, John El-Esposito, Tokoh-Tokoh Kunci Gerakan Islam Kontemporer, Jakarta, Grafindo Persada, 2002.

Karim,M. Rusli, Pendidikan Islam di Indonesia Antara Cita dan Fakta, Yogyakata, Tiara Wacana, Cet I 1991.

Kartanegara, Mulyadhi, Menembus Batas Waktu; Panorama Filsafat Islam, Bandung, Mizan, 2002.

Kartodirdjo, Sartono, Pendekatan Ilmu Sosial dalam Metode Sejarah, Jakarta. Gramedia Pustaka utama, 1993.

Khafidin, Zaenal,"Model Pendidikan "Pesantren Madrasah" dalam Jurnal Penelitian STAIN Kudus, Vol. 2, No. 1, Januari-Juni, 2008.

Khamami Zada, Neraca Gus Dur di Panggung Kekuasaan, Jakarta, LAKPESDAM, 2002.

Khozin, Wakhid, dkk, Pendidikan Kewargaan Pada Komunitas Pesantren, Jakarta, Prasasti, 2007.

Khuluq, Luthiful, Fajar Kebangunan Ulama; Biografi K.H. Hasyim Asy'ari, Yogyakarta, LKiS, 2000.

Kosasih, E., Hak KH. Abdurrahman Wahid untuk Nyeleneh, Yogyakarta, Pustaka Hidayah, 2000.

Manan, Nawawi A. dkk, Menguak Misteri Presiden Indonesia ke 7, Jakarta, Pasardesa Press, 2008 .

Mardiyah," Kepemimpinan Kiai dalam Memelihara Budaya Organisasi; di Pondok Modern Gontor, Liboyo Kediri, dan Pesantren Tebuireng Jombang”, dalam Jurnal Tsaqafah, Vol. 8, No. I. April 2012.

Marzuki dkk, Pesantren Masa Depan, Wacana Pemberdayaan dan Transformasi Pesantren, Bandung, Pustaka Hidayah, 1999.

Mas'ud, Abdurrahman, Intelektual Pesantren Perhelatan Agama dan Tradisi, Yogyakarta, LKiS, 2004.

Masdar, Umaruddin, Membaca Pikiran Gusdur dan Amien Rais Tentang Demokrasi, Yogyakarta, Pustaka Pelajar, 1998.

Mastuhu, Dinamika Sistem Pendidikan Pesantren, Indonesia, Netherlands coorporation in Islamic Studies, seri Inis, XX, Jakarta, 1994.

Miriam Cooke dan Bruce B. Lawrence (ed), Muslim Network From Hajj to Hip-Hop,

USA, The University of Nort Carolina Press, 2005.

Miskawaih, Ibn, Tahzî̉b al-Akhlâq wa Tathîr al-A 'râq, Mesir, al-Matba'ah al-Misriyah, cet. I, 1934.

Mochtar Affandi, Membedah Diskursus Pendidikan Islam, Jakarta, Kalimah Cet I, 2001.

Moeleong, Lexy, Penelitian Kualitatif, Bandung, Rosdakarya, 1995.

Moeliono dkk, Kamus Besar Bahasa Indonesia, Jakarta, Departemen Pendidikan dan Kebudayaa, 1990.

Muarif Ambary, Hasan, Menemukan Peradaban: Jejek Arkeologis dan Historis Islam Indonesia, Jakarta, Logos, 1998.

Mubin, H. dan Ma'ruf, Hidayat, Kinerja Manajmen dan Proses Pembelajaran pada Pondok Pesantren Ibnul Amin Pamangkih, Rasyidiah Khaudiyah Amuntai, Darussalam Martapura, 2002. 
Mudzhar, Atho, "Pesantren Transformatif: Respon Pesantren Terhadap Perubahan Sosial", dalam Jurnal Edukasi, Jakarta, Puslitbang Pendidikan Agama dan Keagamaan, Volume 6. No. 2, 2008.

Muhadjir, Noeng, Metodologi Penelitian Kualitatif, Edisi IV, Yogyakarta, Reka Sarasin, 2002.

Muhaimin, Nuansa Baru Pendidikan Islam, Jakarta, Rajawali Press, 2006.

Muhammad, Husein, "Kontektualisasi Kitab Kuning: Tradisi Kajian dan Metode Pengajaran", dalam Marzuki Wahid dkk (Peny), Pesantren Masa Depan Wacana Pemberdayaan dan Transformasi Pesantren, Bandung, Pustaka Hidayah, 1999.

Muhammad, KH. Husein, Sang Zahid Mengarungi Sufisme Gusdur, Yogyakarta, LKiS, 2012.

Mujahidin, Endin, Pesantren Kilat Alternatif Pendidikan Agama di Luar Sekolah, (Jakarta, Pustaka Al-Kautsar, 2005.

Mujani, Saiful, Muslim Demokrat; Islam Budaya Demokrasi, dan Partisipasi Politik di Indonesia Pasca Orde Baru, Jakarta, Gramedia Pustaka Utama, 2007.

Mulkhan, Abdul Munir dkk (ed), Rekonstruksi Pendidikan dan Tradisi Pesantren Religiusitas Iptek, Yogyakarta, Pustaka Pelajar, 1998.

Murshafi, Muhammad Ali, Bagaimana Mendidik Anak Agar Cerdas dan Berbakti, Surakarta, Ziyad Vizi Media, 2009.

Musa, Ali Masykur dkk, Buku Putih Menegakkan Kebenaran, Kesaksian Fraksi Kebangkitan Bangsa DPR RI, Tentang Dana Yanatera Bulog dan Bantuan Sultan Brunei, Jakarta, FKB DPR RI, Jakarta, 2000.

Nakamura, Mitsuo, Agama dan Perubahan Politik-Tradisionalisme Radikal NU di Indonesia, terj. Surakarta, Hapsra, 1982.

Nasution, S, Pengembangan Kurikulum, Bandung, Citra Aditya Bakti, cet ke-5, 1993.

Nata, Abuddin, Ilmu Pemdidikan Islam dengan Pendekatan Multidisipliner, Jakarta, Rajawali Press, 2009.

Nata, Abuddin, Pendidikan Berbasis Masyarakat dalam Perspektif Islam, dalam Jurnal Pemikiran Islam Kontekstual "Jauhar", (Jakarta, UIN Syarif Hidayatullah, 2001), Vol.2, No.2.

Natsir Zakaria, Gamal Abdul, "Pondok Pesantren: Changes and Its Future", dalam Jurnal of Islamic and Arabic Education, Vol. 2, University Brunei Darussalam, 2010.

Nawawi, Hadari, Kepemimpinan Menurut Islam, Yogyakarta, Gadjah Mada University Press, 1993.

Nazir, Muhammad, Metode Penelitian, Jakarta, Ghalia Indonesia, 1988.

Niam, Mukafi, NU Online. Diakses tanggal 3 Maret 2014.

Nilan, P,'Spirit of Education' in Indonesian Pesantren, British Journal of Sociology of Education, 2009.

Nizar, Samsul et. al, Sejarah Sosial dan Dinamika Intelektual Pendidikan Islam di Nusantara, Jakarta, Kecana, 2013.

Noer, Delier, Gerakan Modern Islam di Indonesia 1900-1942, Jakarta,LP3ES, 1998.

Osman Bakar, Hierarki Ilmu Membangun Rangka-Pikir Islamisasi Ilmu, Bandung, Mizan, 1992.

-Psikologi, Jakarta: Pustaka Al-Husna, Cet III,1985.

Pulung Sudibyo, Rahmat,'Integrasi, Sinergi dan Optimalisasi dalam Rangka Mewujudkan Pondok Pesantren Sebagai Pusat Peradaban Muslim Indonesia”, Jurnal fakultas 
Pertanian dan Peternakan, Universitas Muhammadiyah Malang, Volume 13, No. 2 Juli-Desember, 2010.

Qomar, Mujamil, Pesantren dari Transformasi Metodologi Menuju Demokratisasi Institusi, Jakarta: Erlangga, 1999.

Quthub, Sayyid, Tafsir Dhilal al-Qur'an, (Beirut: Dar al-Ahya, tt, Juz XV.

Rabie, Hamdi A., Islam Sebagai Kekuatan Internasional, Bandung, Rosda Karya, 1998.

Raehani, Curriculum Construction in the Indonesian Pesantren, Koln, Lambert Academic Publishing, 2009.

Rahardjo, Dawam, Pergulatan Dunia Pesantren, Jakarta: P3M, 1985.

Rahardjo, Pengantar Sosiologi Pedesaan dan Pertanian, Yogyakarta, Gaja Mada University Press, 2013.

Rahim, Husni Madrasah dalam Politik Pendidikan di Indonesia, Jakarta, Logos Wacana Ilmu, 2005.

Rahman, Fazlur, Islam, Yogyakarta: Pustaka Pelajar, 2000.

Ramayulis dan samsul Nizar, Ensiklopedi Tokoh Pendidikan Islam, Jakarta, Ciputat Press, 2005.

Ramli, Andi M., Gambaran Singkat tentang Pendidikan di Pesantren, dalam Buletin Bina Pesantren, Jakarta, Depag RI, Juli 1999.

Republika 10 April 2012.

Ridha, Muhammad Rasyid, Tafsir Al-Qur'an al-Hikam; Tafsir al-Manar, Juz VII, (Beirut: Dar al-Fikr, tt.

Ridwan,Nur Khalik, Suluk Gusdur, Bilik-Bilik Spritual Sang Guru Bangsa, Aruzz, Media, 2013.

Rosyada, Dede, Paradigma Pendidikan Demokratis; Sebuah Model Pelibatan Masyarakat dalam Penyelenggaraan Pendidikan, Jakarta, Kencana, 2003.

Rosyadi, Khoirul, Mistik Politik KH. Abdurrahman Wahid, Yogyakarta, Jendela, 2004.

Ruswan dan Darmuin (ed), Pemikiran Pendidikan Islam Kajian Tokoh Klasik dan Kontemporer, Semarang, Fakultas Tarbiyah IAIN Walisongo Kerjasama dengan Pustaka Pelajar, 1999.

S. Nasution, Asas-asas Kurikulum, Jakarta, Bumi Aksara, Cet 2, 1995.

Sabda, Syaifuddin, Desain, Pengembangan dan Implementasi Model Pengembangan Kurikulum Terpadu IPTEQ dan IMTAQ, Jakarta: Ciputat Press, 2006.

Saefuddin Zuhri, Guruku Orang-Orang dari Pesantren, Yogyakarta: LKiS Cet, ke-1, 1994. Saefuddin,A.M. et al, Desekularisasi Pemikiran: Landasan Islamisasi, (Bandung: Mizan, Cet IV, 1998.

Saleh, Abdurrahman, Konsepsi dan Pengantar Dasar Pembaharuan Pendidikan Islam, Jakarta, DPP GUPPI, 1993.

Sangarimbun, Nasri,'Tipe Metode dan Proses Peneltian", dalam Metode Penelitian dan Survei (ed), Nasri dan Sopyan Effendy, Jakarta, LP3ES, 1987.

Saridjo, Marwan, Pendidikan Islam Dari Masa ke Masa; Tinjauan Kebijakan Publik terhadap Pendidikan Islam di Indonesia, Jakarta, Yayasan Ngali Aksara, 2010.

Sarkom,"Pembaharuan Pemikiran Pesantren", Blog pribadi, 2010, diakses tanggal 21 Mei 2013.

Sartono Kartodirjo, Religious Movement of Java in the $19^{\text {th }}$ and $20^{\text {th }}$ Centuries, Yogyakarta, Faculty of Letters Gadjamada University, 1970

Shalih Abd'Aziz dan Abd Majid, al-Tarbiyah wa Thuruq al-Tadris, (Mesir: Dar al-Ma'arif, tt. 
Shihab, M. Quraish, Membumikan al-Qur'an, Bandung: Mizan, 1999.

Sidi, Indra Djati, Menuju Masyarakat Belajar, Menggagas Paradigma Baru Pendidikan, Jakarta, Paramadina, 2001.

Sidik, Suheri, Khulasah Sirah KH. Abdurrahman Wahid, Surabaya: Dunia Ilmu,1999.

Soebadio, Haryati, Catatan Mengenai Metode Penelitian dan Filsafat Ilmu Pengetahuan Khususnya Bidang Ilmu Sosial, tidak diterbitkan, Diktat, 1998.

Soebahar, Abd. Halim, Wawasan Baru Pendidikan Islam, Jakarta, Kalam Mulia, 2002.

Steenbrink, A. Karel, Pesantren Madrasah Sekolah, Jakarta, LP3ES, 1986.

Sudjana, Anas, Pengantar Administrasi Pendidikan Sebagai suatu Sistem Bandung, Rosda Karya, 1997.

Sugiyono, Metode Penelitian Pendidikan Pendekatan Kuantitatif, Kualitatif dan $R \$ D$, Bandung, Alfabeta, 2006.

Suhemi, Ahmad, Dari Kanan Islam Hingga Kiri Islam, Jakarta, Darul Falah, 2001.Sukamto, Kepemimpinan Kiai dalam Pesantren, Jakarta, Pustaka LP3ES, 1999.

Sukmadinata, Nana Syaodih, Metode Penelitian Pendidikan, Bandung, Remaja Rosda Karya, 2008.

Suminto, Aqib, Politik Islam Hindia Belanda, Jakarta, LP3ES, 1996.

Supriyanto, Eko, Inovasi Pendidikan; Isu-Isu Baru Pembelajaran, Manajemen dan Sistem Pendidikan di Indonesia, Surakarta, Universitas Muhammadiyah Press, 2004.

Surya, Muhammad, Psikologi Guru; Konsep dan Aplikasinya, Bandung, Alfabeta, 2013.

Suwendi, Sejarah dan Pemikiran Pendidikan Islam, Jakarta, Raja Grafindo Persada, 2004.

Suwito NS,"Model Pengembangan Ekonomi Pesantren", dalam Jurnal Penelitian pendidikan Agama dan Keagamaan, Volume 6 Nomor 3 Juli -Seprtember 2008.

Suwito, Konsep Pendidikan Akhlak Menurut Ibn Miskawaih, Jakarta, UIN Syarif Hidayatullah Jakarta, 1995.

Suyoto"Pesantren dalam Alam Pendidikan Nasional," dalam M. Dawam Raharjo (ed), Pesantren dan Pembaharuan, Jakarta, LP3ES, 1995.

Syafaruddin, Kepemimpinan Pendidikan; Akuntabilitas Pimpinan Pendidikan dalam Konteks Otonomi Daerah, Jakarta, Ciputat Press, 2010.

Syafi'ie Noor, Ahmad, Orientasi Pengembangan Pendidikan Pesantren Tradisional, Jakarta, Prenada, 2009.

Tafsir, Ahmad, Ilmu Pendidikan Islam, Bandung, Remaja Rosdakarya, 2012.

Tilaar, H.A.M., Pendidikan Dan Pembangunan Nasional Menyongsong Abad XXI, Jakarta, Balai Pustaka, 1998.

Tim INCReS, Beyond the Symbols; Jejak Antropologis Pemikiran dan Gerakan Gus Dur, Bandung, Remaja Rosdakarya, 2000.

Tim Peneliti, Peran Pesantren Dalam Penyelenggaraan Program Wajib Belajar 9 Tahun, Jakarta, BalitBang Kemenag RI, Pusat UIN Jakarta, 1999.

Tim Penyusun, KH. Imam Zarkasyi; Dari Gontor Merintis Pesantren Modern, Ponorogo, Gontor Press, 1996.

Tomo, Wahyoe, Penguruan Tinggi Pesantren; Pendidikan Alternatif Masa Depan, Yogyakarta, Gema Insani Press, 1997.

W.J. S. Poerwadarminta, Kamus Umum Bahasa Indonesia, (Jakarta: Balai Pustaka, 1991.

Wahid, Abdurrahman, Bunga Rampai Pesantren; Kumpulan Karya Tulis Abdurrahaman Wahid, Jakarta, Dharma Bhakti, 1984.

Wahid, Marzuki dkk, (Penyunting), Pesantren Masa Depan, Wacana Pemberdayaan dan Transformasi Pesantren, Bandung, Pustaka Hidayah, 1999. 
|SAMSUL BAHRI| Pemikiran KH. Abdurrahman Wahid...

Wahidin, Khaerul, Pembaharuan Pondok Pesantren Masa Orde Baru, Disertasi (UIN Syarif Hidayatullah Jakarta, tidak diterbitkan, 2000.

Weber, Max, Essay in Sosiologi, terj. Noorkholish, Yogyakarta, Pustaka Pelajar, 2009. 